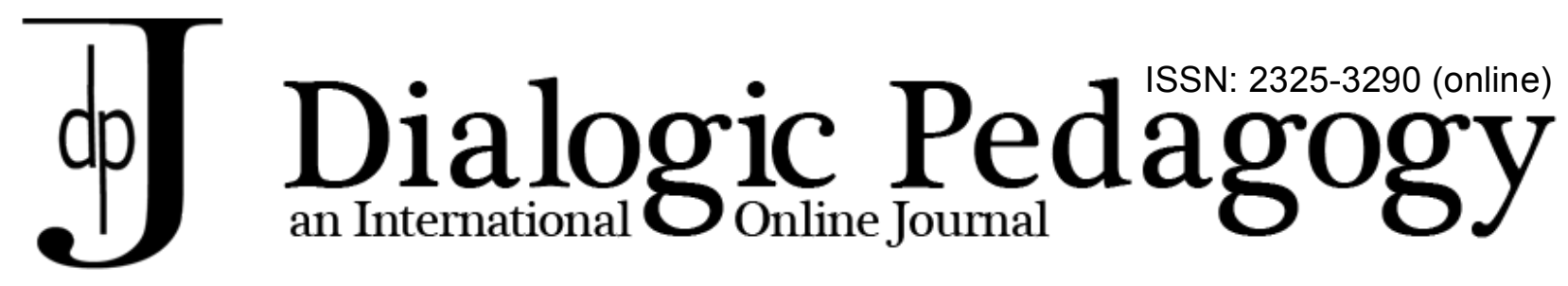

\title{
I thought you'd never become one of us
}

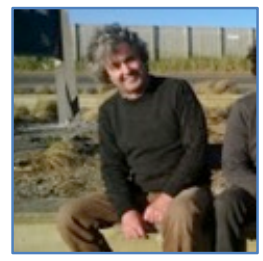

Charles Bisley

Kelburn Normal School, New Zealand

\begin{abstract}
In this paper, I describe a collaborative process in which a class of grade $6 \& 7$ students made and performed two plays, and also transformed their learning. In this process, a reconfiguring of the spaces of learning, the students and I adapted a variety of literacy and drama practices; a key change in practice was the shift away from an instrumental mode of dialogue in which the teacher occupies the superior position of knower and evaluator, towards a Bakhtinian mode in which dialogue, as heteroglossic, moves between all the participants, and becomes the main purpose of learning. In a dynamic combination of linguistic, theatrical, and relational meaning making, the students moved clear of the outcomes-based learning that had hitherto stultified their interactions and language. As a result, they developed a new creative agency, both singly and as a collective, and an authoritative discourse. They left this discourse open for me to join, and also continue afterwards, as I have done here, by presenting and interpreting their voices, and including new ones. ${ }^{1}$
\end{abstract}

Charles Bisley is a teacher and the Curriculum Leader at Kelburn Normal School, in Wellington, New Zealand. There he leads participatory action research into ways to develop the school's curriculum to empower all students. He has a background in the performing arts, and draws on all the arts to make learning, particularly in literacy, a creative collaboration. He teaches students from $\mathrm{K}$ to Grade 7, with an emphasis on Grade 4 to 7. He is the Vice President of Drama New Zealand, the national organisation for drama teachers and researchers across all sectors. He is also on the editorial boards of two academic journals, and in his spare time writes poetry.

\section{Acknowledgement}

I would like to express my appreciation to Ana Marjanovic-Shane and Bojana Skorc, the Managing Editors, and also to the reviewers, for their constructive responses which helped me to improve this article considerably. Also to my colleagues at Kelburn Normal School for the wider conversation and research this project was part of, particularly Linda Kingston, Alistair Button, Justine McDonald, Michelle Hunt, and Danielle Sanders. And finally my co-authors, the children of Senior Additional English Room 2010, who created the momentous events I describe here.

\footnotetext{
${ }^{1}$ EDITORIAL NOTE: Charles Bisley's article is an unusual and brave attempt to transcend the current norms of scholarly and academic genres and create a polyphonic article in which he describes a year long educational event through the voices of all of its participants - among which he counts not only his students and himself, and their audience of parents and the school authorities, but also includes educational, literary and philosophical authors who inspired him and whose thoughts guided him in his actions and reflections during and after his project in creating dramatic spaces and times with his students. His writing has elements of reflective auto-ethnography, Woolfian lyrical stream of consciousness, dialogic double-voicedness and a storytelling narrative that is intended to transport the reader into an experience of the dramatic enfolding of the events and their protagonists, actors and directors: his students and himself. Although, his work doesn't follow what is currently assumed to be the scientific criteria regarding form, length or standard components, we find it interesting and valuable as a polyphonic approach and qualitative study.
} 


\title{
1. An unforeseen inquiry
}

\begin{abstract}
"I am always answerable for the response that is generated from the unique place I occupy in existence. My responses begin to form a pattern: the dialogue I have begins to assume the form of a text, a kind of book" (30).
\end{abstract}

Michael Holquist

It's late in the last term and the children are busy, rehearsing their parts in our new play Sooner or Later. There are twenty eleven to thirteen year olds in the Rainbow Room, a space designed for fifteen five year olds. In a few days we're off to The Gryphon - a theatre in town - and l'll have my hands full then. Right now though, I'm sitting at my desk with the script.

And there's Maisie. She's stepped into the little gap right before my desk. She has her stern listen-to-meMr-Biz face. Look, this is serious! She's taken up by what she has to say to me:

Maisie: I thought you'd never become one of us.

She says it and that's that. Maisie, she's not only deep, as the kids say, but she's also learnt to put it out there.

I was just one of the play makers, and the kids were working closely together, in an independent phase. The atmosphere was convivial; their talk was all about the play, and between them, mostly. There were eddies of quiet too.

Maisie's announcement took me by surprise. One of them was the last thing I thought l'd be. From the beginning, l'd offered these kids new practices and roles so that they could take the learning away from me, from my superior role as knower and evaluator. So as time went on, l'd taken great satisfaction in watching one asymmetry replace another. As playmakers and performers, the children had brought their higher imaginative powers to the fore.

And they'd also become researchers, in their own way. When I set this research process in motion, I knew I wasn't going to get far without their ideas and questions. I backed the kids to take an active part in the process, even if I had to wait for them to do so. I didn't have a method for them, and one consequence was the kids had set off on inquiries of their own.

I took it that Maisie was answering a question she'd come up with about me. Her answer came across as more about the class than me, as an afterthought to another inquiry, perhaps. It's not that I doubted her word about me- it's just I felt I was borderline. Her words came from some way off, from them. And if I were really part of this 'us', how come I hadn't understood that myself?

Around the performances of the two plays- first, thank you for holding and then, Sooner or Later, the class became coherent a new way. Despite the fact that they were still pulling in so many directions, they also were pulling together. I saw their creative agency as a group, and l'd call this polyphony now, to use Bakhtin's metaphor.

And later I came to ask what if, along with their play, this class had created their own way of learning, and a language to go with it, an internally persuasive discourse that took over from instructional language, from its authoritarian discourse? Was their authorship of this discourse the dialogical struggle which Bakhtin describes as determining "the very basis of our ideological relationship with the world"? 
(Discourse 342). Maisie spoke with authority, and from then on, I felt I had to answer her somehow, and the class she represented. As I didn't understand this new dialogue, I would have to take it further, write a new one of my own.

Gary Saul Morson: "We not only learn, we also learn to learn, and we learn to learn best when we engage in dialogue with others and ourselves. We appropriate the world of difference and ourselves develop new potentials. These potentials allow us to appropriate yet more voices" (331).

\title{
2. Dialogue, means or end?
}

\begin{abstract}
"The relation between educator and student is a power relation by virtue of the practice itself. No amount of dialogue will change the fact that in this relation one party determines the grades and the other does not, one possesses the knowledge that the other does not (or not in the same measure), and one partakes of an institutional power that the other does not" (561)
\end{abstract}

Paul Fairfield

To finish off its practice each week, Piccolo sings The Miller of $D e e^{2}$. It's a melancholy number, best with the lights off, the room in shadow. The kids like the ritual, the quiet afterwards; even if the next class is bumping around outside, they hold still and savour the moment. But the other day Mira - a grade 3 student - interrupted the quiet to ask me.

Mira: Why do you turn the lights off for the song?

I was puzzled - wasn't this Piccolo's secret custom, one the newbies followed the others on? Mira's question seemed rhetorical, so I turned it back to her with a why do we? When she said nothing, I added a you know, don't you? She smiled in seeming agreement, but then asked again. I paused, puzzled by her insistence. Meanwhile some of the next class had snuck in, and were watching. One of them, Claudia, ten, took her chance.

Claudia: Mr Bisley... it's because teachers ask so many questions... and they always know the answers.

Claudia's quite the observer, and not one just to step in. The audience of her peers enjoyed her move, seemed right behind her. He's a teacher, and even if you told him how it was for us, would he get it?

Claudia's answer took me back to Maisie's. As one class took themselves off, the next got ready. I didn't have anything to say to Claudia; however, this encounter seemed the reverse of the other. I felt isolatedMira's words had pushed me right away from the class. Was her question a comeback, for both that stream of rhetorical questions we teachers ask, and also the questions that maintain us as the experts, and the kids as subordinate.

The kids were right- I was the one with my finger on the switch. And yet the class's response, their mutual recognition of their subordinate role, their limited agency as learners at school, reminded me there were other conversations and worlds they were part where they had more agency. Brought back Maisie's us.

${ }^{2}$ At Kelburn Normal School I teach two literacy classes, and a variety of performing arts ensembles, including Piccolo, a choir for grade 3-5 students. 
Paul Fairfield reminds us that the educational relation is a power one by virtue of the practice itself. In my school, the power relation often goes unremarked, and I don't kid myself that this practice isn't ingrained in my work too. Our children are used to, depend on it. Dialogue- that won't change things on its own; instead my approach has been to work around the problem, to open up many fronts on it. If I developed alternative language practices- plural, dialogic, and aesthetic- with kids, might they also think differently about the way they learnt?

In 2010, for the research project described here, l'd set up adopting such alternative linguistic and aesthetic practices as our main action. How could we adopt and adapt literacy to loosen the language that framed it, and find more space, other spaces for the class's voices and thoughts? I planned, specifically, to experiment with a literacy/drama blend that would offer the kids to collaborate on a playmaking and performing project, and reconfigure the socially restrictive space that went with standardised literacy ${ }^{3}$.

I've often thought about arguments that dismiss schools as places for learning. Taking these into account, I'm developing an argument here about how this class's alternative practices changed the power relation inside a school ${ }^{4}$. In The Ignorant Schoolmaster, for example, Jacques Ranciere contends that the teacher, because of his institutional role as knower, and the fixed language that goes with that role, can't teach his students to speak their thoughts, and can't therefore establish a relation of equality with them.

Charles Bingham \& Gert Biesta: "To gain voice in this way would mean that the master needs to tell the learners what they are thinking and saying- which at the very same time 'overwrites' their own thought and speech and denies them their capacity for thought and speech" (140).

Indeed. But children also speak and learn elsewhere, and they can bring these other languages and learnings into school ${ }^{5}$. Claudia and her Piccolo audience, for example, show how knowing kids can be about how they are made to learn, and implies kids know about other learning too, and share this awareness too. What if teachers put aside their magisterial status, and instead gained voice by responding to such learners?

In its early days, I felt that Piccolo push back from Maisie's class too, but push back wasn't all. Some of the children, knowing I did things differently, would give me this curious look, before they'd learnt to speak up and ask. Claudia's mild tone of voice, her tone of candour rather than argument, was similar. I encountered that in this class too- an expectancy. Had they come up with a question about me, like Maisie? Did I have some potential?

The Piccolo encounter represents a further school-wide context that was relevant to this research. Our school has building a powerful learning culture as a strategic goal; in this, developing learning conversations has been the key strategy. Back in 2010, many classes had a clear procedure for this conversation or dialogue, an instructional one deriving loosely from Vygotsky. ${ }^{6}$ The main purpose of this dialogue is knowledge acquisition, and the role of the teacher there, as Holquist describes it, is one of tutor, the one who with more consciousness assists the ones with less.

\footnotetext{
${ }^{3}$ For the first term of this three term project, the three other Grade $6 \& 7$ literacy classes joined with mine to make devising and performing a play the major component of their literacy programme. Each teachers had their own focus; the question we did share was to do with a more open planning process.

${ }^{4}$ Since 2009, other classes I have taught, and other teachers with other classes, attempted similar changes as part of an ongoing process of teacher inquiry and curriculum development at Kelburn Normal School.

${ }^{5}$ I had learnt this from what my own children said to me, from the expressiveness of their language and learning away from school.

${ }^{6}$ Our Vygotsky in use is far from the actual texts, for example our use of the term ZPD for a group teaching situation.
} 
Michael Holquist: "The child needs to cross the distance from one state to another in cognitive space, which is precisely the point where Vygotsky's concept of the zone of proximal development becomes crucial" (82).

In our learning conversations, the child or groups of children cross the distance, guided by teacher modelling and questioning. In teacher speak, their move is "scaffolded" by our questions and prompts; the move across is also up. The scaffold can be quite restrictive. ${ }^{7}$

Although it has worked well well for reaching prescribed cognitive outcomes, this dialogic practice can, as Bingham and Biesta argue, overwrite the children's own language and thoughts. The teacher follows, models and monitors an instructional speech genre that inhibits the expressive voice. The teacher's main role is knower and evaluator, their position higher than the students. Claudia's recent speech and her audience's response, shows how our kids feel about being subject to this interrogative script.

Some of our teachers have been all for it. Doesn't this mode support the basic IRE- initiation, response, evaluation- cycle where learning is sequenced back from its prescribed, cognitive outcome? This instrumental/instructional dialogue, it's second nature to us: anticipate the responses before the lesson; jot down the ones you are looking for; let the discussion run in the groups; to conclude, choose those who can explain the best, who can model the correct concepts; you tidy up their language, put them right. Get the kids to tell you what you told them they were looking for.

Others of us saw this dialogue as a restrictive circle. In our teaching as inquiry, we were trying to loosen the circle, make learning more of a partnership, ${ }^{8}$ and not just in project-based afternoons. It wasn't that the instructional dialogue didn't have its place, but we argued that the basics weren't instructional. And for us the kids' conversations about learning were repetitious, as were teachers'. That's the power of the script, that's what we wanted to put down.

I can see more than I did back then, but I'm representing the perspectives I took back then as well, as they are where I spoke to the children from. So even before I bring in the children's voices, the narration has an open, double-voiced form, the form that Bakhtin describes as "orientated to the discourse of others" (Problem 199). Since I'm not arguing from a single or abstract framework, it remains dialogical as the original process was, and open to the voices of others, open to the voices of others, including new, outside ones, and unfinalised insofar as these voices that may alter and divert my current perspectives as I go.

As for the gaps and discrepancies- both witting and unwitting- between these various perspectives, I'm hoping that readers will not misconstrue them in terms of a logic or form of discourse l'm not attempting.

A controversy occurred at this year's (2014) Dialogic Pedagogy Institute in New Zealand, ${ }^{9}$ which continued as an online discussion in this journal. For me, it pivoted on the difference between dialogue as means or end; its two leading voices further articulated the problem that the dominant dialogic practice in the school presented to me, then (and now).

\footnotetext{
${ }^{7}$ Some schools are now using the acronym DIRT (direct instructional reflective time) for the teacher- led summative phase of this mode of dialogue.

${ }^{8}$ In Aotearoa, New Zealand the Maori concept ako is used to describe reciprocity of the learning relationship. Ako values what the teacher and the student bring; in practice, the power relation can still be asymmetrical.

${ }^{9}$ This followed Dialogue at the Boundaries: The Fourth International Interdisciplinary Conference on Perspectives and Limitations of Dialogism in Mikhail Bakhtin.
} 
Back then, I was influenced by the comparison Cheyne and Tarulli made between Vygotskian and Bakhtinian modes of dialogue in terms of their spatial dynamics. If the Vygotskian is centripetal, towards knowledge acquisition, the Menippean mode in Bakhtin is centrifugal, and driven by the formation of social relationships. They describe how the teacher's voice in Vygotskian dialogue is lent authority from the third, magisterial voice, the authority of the knowledge domain and its discourse. Their interpretation of Vygotskian dialogue corresponds with our dominant mode, and in both, the learner as knower and speaker is subordinate to the teacher. As I planned this research, I was after centrifugal dialogue from the children, the conversations that come from outside of the usual, centripetal discourse, that might move them away form this subordination. They sure needed to interact more with each other, and refer back less to me. Since I saw the magisterial discourse as the anchor of the centripetal, I intended to downplay that too.

Continuing their discussion in an online editorial, Rupert Wegerif argued for dialogic education as dialogue for education, whereas Eugene Matusov argued for dialogue as education.

Rupert Wegerif: It is true that in real dialogue we cannot determine in advance where the endpoint will be. It is also true each child and each student is unique and will have their own unique educational journey. So how can I claim as "dialogic" a curriculum that speaks in advance what is to be learnt?” (E18).

In planning this drama/language blend, I'd thought of dialogue more as a means for making a play, so as dialogue for education, an open ended centrifugal process that could be dialogic in that many of its outcomes were not prescribed. I was sceptical about dialogue as education; with individual students, within a small group or two, but not between a whole class. I had never seen a class take their learning that far from school discourse.

In the first term of the year of this class, I did say to these kids there was only so much I could do on my own. I suggested how the class turned out was up to them as well. I didn't ever say to the kids what their role might be, what kind of community we might become. I didn't lead them along by questions, Socrates style, because I didn't know. My style is to keep my ideas about learning indirect, implicit in other conversations that the kids might respond to.

Playmaking, classmaking. In playmaking I did anticipate how the distinctions between process and product, and means and end, would give way to a dynamic meaning making in which any finalisation would only be temporary. And how dialogue would be key.

I didn't anticipate how dialogue would become both means and end too. As the kids interacted and talked over their fiction together, wouldn't they discover that finding out who they were was implicit in that main fiction and its dialogue, as subtext. So here I'm looking for how, out of the first theatrical linguistic dimension, a second emerged, as subtext, as a meta- or translinguistic dimension even. How could dialogue as a means become dialogue as an end too, dialogue as education?

Maisie's answer has stuck in my mind because it suggests the shift that took place within the aesthetic event. I've been tantalised by the possibility that creativity of the play had become the means for the class's primary task- to create an alternative to "the practice of education itself". 
Caryl Emerson: "[F]or Bakhtin: art is not primarily a matter of pleasure, beauty, perfect proportion, or disinterested play, but the site of another more essential task- knowledge of the self through communicative exchange" (206).

\title{
3. Disparate fictions
}

\begin{abstract}
"The writing person is one who is responsible for him/herself before the world. The writing person is one who dares to be not only inside him/herself, but outside as well. The writing person is one who is ready to be heard by others" (39).
\end{abstract}

Alexander Lobok

The drama/literacy combination had a prequel. For the first term of the year, l'd introduced the kids to more expressive literacy practices, both to give them more agency as language users, and to ready them for the literacy/ drama mix of the following three terms. I knew these literary practices well, seen how they'd opened up literacy for the class of the year before, for example. At that time, the school's literacy practice was largely functional and procedural, a tight fit with the instructional procedure and dialogue l've already described. In writing especially, the kids followed a standard text-type process which Myhill and Locke describe as having been "linearised and fossilised into routines of planning, drafting, editing, revising and presenting" (7) controlled by the teacher.

One shift the class made was responding to texts for their aesthetic qualities. This led them to improvise more in their responses, and to explore unfamiliar forms of language. They also had to improvise more as writers. I knew there was going to be dissonance; l'd got that from the class the year before.

Mary: Strange because when I do normal English, I stress the word NORMAL, I know what to do straight away. It's like my brain is wired a certain way and if you give me something hard and strange to do then I have to like rewire my brain. Does that make sense, do you get it?

Both classes felt this sense of strangeness. This language experience asked so much of them that the kids needed me to understand what it was like but hardly thought I could. In their first terms, the change in the writing process involved a change in learning; the writing that showed this change was the learning letter.

Prior to the learning letter, the kids had formulated and explained their goals, coached by their teachers. I didn't hear any distinctive voices or ideas in these goal monologues. ${ }^{10}$ To address this deficit, I didn't go back to mainly oral reflections, especially since the oral routines seemed to be a comfort zone for many. You are used to not having to say much, and why would you start, especially now you are twelve? Instead, I set up adjoining oral and written reflections over several weeks. In these letters, a lot of the kids spoke up for themselves for the first time. I also heard some skaz.

Mikhail Bakhtin: "Skaz is above all orientation towards the speech of another, and only then as a consequence, towards oral speech" (Problem 191).

\footnotetext{
${ }^{10}$ The year before this research, a New Zealand Council for Educational Research survey of student engagement at our school confirmed our students' low engagement in reflection. To address it, we'd come up with school-wide action research to elicit student voice about learning.
} 
Sally: I know I'm being a bit uncharacteristically naughty at the moment but I'm sick of being good all the time. I'm sick of being Miss Perfect- the one who's only ever gotten one B and one B+. Miss I have gotten only A-, A and A+ the rest of the time. I promise to not do that too often though.

Miss Perfect, On Track. Early on, the class's key question was the am I on track one, on track to a good grade from me that meant. Most of these kids went along with the standard script; however, a small group were more assertive in their compliance, and even monitored and corrected me. l'd try to refer the question back to them, but they knew who was who. Their push back contrasted with Claudia's; they wanted me to lean back in. They tried to play their new class too, but they misjudged their audience. It turned out that most thought the instructional script was, well meh.

David Solway: "It may be regarded an educational fiction almost entirely devoid of ontological pluralisers, those practices and motifs which introduce alternative modes of life and thought into a rigid paradigmatic structure" (17).

As the reactionary phase abated, the class took some pleasure in the new ways- 'going curvy' the previous class called it. This curvy gave both classes their first point of difference, their first identity as a class. I knew that the first class attributed this 'going curvy' to themselves as individuals- it was their capability, not mine, which was good in a way. l'd call it a self-indirectedness.

Marcel: As you may have already noticed, I may not be your usual twelve year old boy. But male or female you could probably apply that to the rest of the class (kettle of weirdos the lot of them).

This second class were eccentrics too. In this class's first learning letters however, there was more dialogue with me, and some confiding even. I took the letters of the eleven l'd observed as socially inhibited, and arranged their letters along a continuum. At one end, there were those who felt shut in, in a state of interrupted flow, like Stella, a Grade 6 girl:

Stella: I really like to write poetry. Not just any poetry. Poetry with meaning that you can feel flowing through you. Like an otter gliding through the water. Slipping and sliding over the rocks. Those rocks are the dead ends, the blocks, the things that slow you down. Man, there must be a lot of rocks in my pond...

At the other end, representing those who were shut out from their ideas we have Miles, a Grade 7 boy:

Miles: It's like my brain was a kingdom, full of ideas. But, in the deepest, darkest reaches of the kingdom there was a wall, a wall that reaches right to the sky, neverending. Behind this wall, are more ideas, and in the wall was a gate, was a large one, it only opens slowly, for the hinges are rusted, and so the ideas come slowly

I realised how little l'd known them. Take Miles, his image of a boy shut out from himself. In class, he'd seemed an agreeable and composed mastery learner. He'd selected the goal to draw on his personal experience in his writing for a couple of years now, but he hadn't, he wasn't that easily drawn. And now this striking and expressive self-image, Wordsworth's 'shades of the prison house' in reverse. I wondered who had built this wall and if I'd been another brick in it. I wasn't about to plonk a scaffold up against these imaginative dramas. Get to work with the loan of consciousness? Come off it! 
If I frame these letters now in the aesthetic and relational terms of Bakhtin's early architectonics - I for myself, I for others, others for me - I find that they mostly express the I for myself. As for the self-other relations, the other is mostly their own self that they are now wondering at, depicting as strange. At the time, I was taken aback that the kids hardly mentioned learning with others. And it wasn't that they weren't agreeable, or adept at the communicative competencies.

l'd believed for a long time that the magisterial voice, the one Cheyne and Tarulli identify in Vygotskian dialogue as the third voice (teachers and students were the other two); could inhibit social learning. In the drama process ahead, I was going to be able to share knowledge more with the kids. And I was looking for the three veterans from last year's class- Clara, Holly, Sally- to take the lead in the class's social interactions. They'd experienced these more than the others, and were clearly frustrated by their new class's lack of responsiveness.

Clara: As you have probably noticed, I have changed slightly from last year, maybe not particularly in the way I wanted, but it's a start. If people have noticed they keep it to themselves- not everyone's ears are open to hear.

One other thing. I said I wasn't going to grade these letters and the kids questioned that. I wrote back instead. I felt self-conscious- my responses would have come across as an exercise.

I didn't know much Bakhtin at the time; if I had, would I have been able to follow the class as far as I did, as far out? I didn't have a relevant theoretical framework, and so I had to improvise ${ }^{11}$. I did have characters from novels representing the imaginative prowess and perspectives of children to guide me, to enhance the picture I had from my students already. As for the kids, expert knowledge might have elicited if not more of the am-I-on-track response, the feeling of being subject to the Socratic question and answer procedure. I may not have been as open to their other for me.

In the event, I learned from meanings ingrained in life, and that's Bakhtinian isn't it? And here, If I do succeed in my attempt to pass up through the gates of the chronotope, I will need to hold onto those meanings.

It's not that easy to stop being superior. To Maisie, a sympathetic observer, it didn't look as though l'd do it.

At the end of the prequel term, the impersonal on-track check-in with the teacher was rare. In the next, the first play term, playful flourishes on the subject of learning started to appear, flourishes that showed there was an audience in on the joke, a joke I was complicit in too.

Scarlet: Oh no! Now I'm distracted from my thought train! It veered off course and I can't seem to get back in the right direction.

\title{
4. A reconfiguring of learning.
}

\begin{abstract}
"Theater [...] is material and ephemeral, and recognises that meaning is made not only in the symbols, metaphors and narratives of drama, but between spaces and places, in the gaps and the silences of reflection as well as in the movement and activity of practice" (214).
\end{abstract}

\footnotetext{
${ }^{11}$ The voices of children like Mick Kelly in Carson McCullers' The Heart is a Lonely Hunter and the orphan, Alfgrimur in Halldor Laxness's The Fish Can Sing, had long spoken to me.
} 
I staged the opening of the second term in two ways - setting process drama in motion, as a vehicle for improvised language and thinking, and at the same time, reconfiguring the learning space of the class, to provide aesthetic and interactive learning spaces. Within this duality, the kids would be able to extend their repertoire of curvy literary practices into a plurality of creative language practices- literary, digital, authentic, critical - aka Multiliteracies.

Bill Cope and Mary Kalantzis: "In a pedagogy of Multiliteracies, all forms of representation, including language, should be regarded as dynamic processes of transformation rather than processes of reproduction. That is, meaning makers are not simply replicators of representational conventions" (175).

My dual design provided the frame for my main research action, combining drama and literacy with the purpose of empowering student voice, and reflectiveness. In contrast with the tight framing of functional literacy, in process drama, in the theatrical spaces, the outcomes frame could be loosened further, the literary and aesthetic approach to meaning of the prequel enhanced.

Jonathon Neelands \& Tony Goode: "To be too definite and clear about the learning intentions and focus of the work in advance is to deny students the power and experience of being artists" (5).

If your kids are going to work as artists, l'd go further and say you have to give them time to develop their own learning intentions and focus. And, looking back, that a long running and open drama process is needed for this creative incubation and emergence. Back then, I envisaged that over the next three terms, the kids would create meaning by moving between the three phases of the drama process- making, performing, reflecting- which they could be take up in any order, in contrast to the fixed, instructional sequence.

Furthermore, I wanted the kids themselves to be subject to an interactive process- one that made them creative, that worked both for and on them by taking them out of themselves, of the selves that I saw isolated many in class.

Michel Foucault: " $[. .$.$] we should not have to refer the creative activity of somebody to the kind of$ relation he has to himself, but should relate the kind of relation one has oneself to a creative activity..." (351).

I also planned departures from the standard drama process. In that process, the making phase is where meaning is made, largely improvised meaning in the oral mode. In our combined practices, however, I saw meaning making move between all three phases, and also, that no mode of language would be privileged. I was confident that written language and scripts could enhance play and creativity, even though the orthodoxy holds they do the reverse.

After more mobility for these young creators, I set up a hybrid process in which a theatrical aesthetic and the drama process could complement each other. I also knew, from many performances (including of the most recent play, Never Never) that young actors can experience a culmination of meaning in realising their character and play fully, on stage. In this heightened theatrical experience, what Mihaly Csikszentmihalyi calls flow, many young actors discover a new sense of agency. 
Erin: When I said that last word, I felt tears welling in my eyes, because it was at that precise moment in time that I realised Never Never was over, done and dusted...I then began to feel my sense of achievement. How did we pull it off? How did I turn my part from a daydream into this?

Erin's use of I and we shows she recognises her own and her class's effort and agency. By contrast, this new class hadn't experienced this joint agency. First move- an improvising phase. l'd introduce process drama and its conventions, the conventions which Neelands and Goode describe as a repertoire of shared meaning-making forms derived from theatrical art, "mainly concerned with the process of theatre as a means of developing understanding about human experience and theatre itself " (7). After some hesitations, the kids would adopt these strategies avidly to explore the inquiry questions, improvising setting, character, imagery and plot, and building a fictional world. These practices, when combined with drama games, would be disinhibiting, invite interaction.

In process drama, you imagine a fictional world where you take up roles and share perspectives; from there, you can think critically about this world. Some in this class really needed an active, shared fantasy, given their solitary absorption in escapist ones. And that's where the next phase, performance would come in- if you present scenes in the aesthetic and semiotic 'outside' spaces of the stage, your meanings become part of a shared, immediate world.

Caryl Emerson: "In Bakhtin's view, art was an active co-creation of images that served to link an individual person responsively to an immediate reality. As such, it posited a sort of aesthetic activism" (209).

The configuring and combining of learning spaces, of actual and imaginary, of private and social, of verbal and aesthetic, I didn't know where that would take us. What if there were multiple spaces, each with its own immediacies, each adjoining on all the others, where the children could make and act out their fiction? In my centrifugal bias, I was also anti-centric. Instead of this order, I envisaged role playing as a common practice, providing coherence across the five spaces. I like the mobility of role playing; kids can move from playing themselves through improvising a character to fully realising a character in the semiotic space of the stage ${ }^{12}$.

The planned reconfiguration: First, a circle of chairs, for speaking; second, the floor, for improvising and devising; third, exercise books, for journaling; fourth, the stage, for performing; fifth, online, for a forum. I anticipated these five different actions as mixing; for example, improvising and performing, or speaking and writing. Also, that they would invite different audience interactions.

Patrick Verriour discusses the key relation of the speaker to the audience, in terms of the increasing distance to the audience as the play moves through different phases of devised presentation, to performance. He agrees with Moffat that students should have "an emotional mandate to play the symbolic scale, to find subjects and shape them, to invent ways to act upon others, and to discover their own voice" (87).

Patrick Verriour: "If, however, educators truly believe that drama offers children the opportunity to play the entire symbolic scale in a range of different language contexts, then they should also be

\footnotetext{
${ }^{12}$ The three stages I use correspond to the five stages of role from dramatic playing (playing yourself in a fictional context) through role playing (sustaining a point of view not necessarily your own) to acting ( fully embodying a character for an audience) described by Morgan and Saxton (1987).
} 
aware of the ways in which drama's differing modes of expression and communication can be integrated with the process of teaching children language" (89).

I did believe in finding the width of the scale, and intended to initiate a drama/literacy blend that worked both ways. The five spaces configuration would enable verbal language contexts, and drama's various modes to be co-ordinated.

Seven months after the class had disbanded, some now ex-pupils came back to say hello. The next thing I knew, they were improvising on an old forum, creating a sequel to their last play, Sooner or Later. This writing had a characteristic out-loud and skaz quality. I was amazed that they picked up with their old characters and each other, just like that.

Kathleen Gallagher: "The built-up context and the improvised development of the characters leave open spaces for unpredictable engagement, for those moments of identification, unknowable to the teacher, that a player might make with the fiction" (90).

If you put together take a group of zany kids ${ }^{13}$, invite them into a fictional world and reconfigured spaces, you don't know where they'll go with it. Or how they might revive their story This resurgence of meaning, long after the event, was a social occasion; it shows how the kids' unpredictable engagements with their fiction weren't only individual, but made in relation to their co-authors.

In this sequel, Maisie plays Shiraz. Shiraz used to be sweet in her capsule in the Arcades, but in the play she rebelled. Now she's being punished by Hoss, the Digital Authority (more on him later). Despite the informality and humour of her writing, Maisie is slyly artfully dramatising a serious paradox that l'd once introduced to the class, that cyberspace's fullness was vacuous.

Maisie/Shiraz: This isn't as snug as my capsule, is it. No. This is all empty and I can't bear it. Every thing is empty and I can't see my reflection in the greasy mirror. Hosssss is still gathering more and more sss's to put at the end of his name and soon the world will be too small to fit all his ss's. They will suffocate us. But don't worry, it is sooner now and that is later. Make the most of the emptyness until we can't breath anymore.

On the bright side pink is my favourite colour again!

I was confident that the collaborative role play of the drama process would extend into a more collaborative approach to literacy, writing especially. I intended to join the role plays, to be more collaborative myself. As the spaces could be worked in outside of school, and the kids learnt differently there, I wondered how this other learning might evolve, and what its effect on school might be. Outside of school, some kids show more initiative; in the digital space these kids would take over my teacher role, some with alacrity.

Sally: And also, Mr Bisley, Kim, Clara, Andrew and Stella, you all seem to have ideas about how it would work.

If I were describing our meaning-making practices now, l'd rephrase them not as a dual drama and literacy ( a duality which invites factionalism) but as a three-fold combination, of linguistic, theatrical, and

${ }^{13}$ This school offers a differentiated curriculum; these kids had been identified as divergent and creative learners (not for their grades, which varied) and had been grouped together to learn in a less instructional environment. 
relational meanings ${ }^{14}$. Regretting the class's lack of responsiveness towards her in its first term, Clara anticipated the learning ahead as a similar combination - relational, linguistic and somatic.

Clara: I like experiencing people you hardly know, thinking with their brain, speaking with their mouths. I like knowing what they're thinking. How they're thinking. Knowing their mind and what makes them tick. This is all a subtle part of the unexplored world of drama.

Unexplored in that the children hadn't encountered it yet, and also in that it would always be so because they'd find meanings as much in the gaps and silences of its forms, and the gaps between their makers too.

\title{
5. The subject as an event
}

\begin{abstract}
"If someone is to say something to us, it is not enough that there should be a so-called recipient who is there to receive the information. For over and above that there must be a readiness to allow something to be said to us. It is only in this way that the word becomes binding, as it were: it binds one human being with another. This occurs whenever we speak to one another and really enter into genuine dialogue with one another" (106)
\end{abstract}

Hans Georg Gadamer

I like asking kids questions about the future, because I don't need to pretend to not know the answer. I like to begin a drama by sitting there with the children, with a question they didn't see coming.

Mr Bisley: What if technology evolves to the point where humans are no longer needed or desirable?

The drama's first question, and the class was subdued. Benedict asked if this was The Matrix, and that drew some smiles. It was 2010, the third year of Twilight at Kelburn Normal School. Vampires were cool, dystopia was still a minority interest. The kids went off into small groups and came back with their own brainstorms, brain puffs more like, and I wrote their words on the board.

Brainstorm \#1: technology, artificial intelligence, robots, science, space, the Big Bang, nature, environmental degradation, extinction, Power, war, slavery, aliens, God.

The words came, but the kids seemed indifferent to the subject.

In arguing for the lesson as dialogic, analogous to the polyphonic novel, and for the teacher as the author as described by Bakhtin, Miyazaki presents Kihaku Saitou's pedagogy as that, "between children, teacher, and teaching material should be generated contradictions, oppositions, confrontations, and conflicts. Children and teacher should, going beyond the oppositions, discover and create new views, and go over to the new horizons" (203).

I like to suggest new views; I like to provoke tensions between me and the kids. In this case, I felt l'd gone too far. My material seemed right out of sight for all but a few.

\footnotetext{
${ }^{14}$ Here I don't use O'Toole et al's authoritative categorization of drama into four paradigms of purpose as linguistic/communicative, expressive/developmental, social/pedagogical and aesthetic/cognitive (6), a categorisation because I don't find these paradigms separate in practice.
} 
Clara: [...] there we were, sitting harmlessly around, gathered in a quiet conversation. This is the first time we hear of the singularity, hear of the play, and know of what is going to happen. Let's end here, at this unsuspected moment $[\ldots]$

It was quiet alright, and for a whole week! Then Martine had had enough. She wanted to get back on track, and get me back on.

Martine: Haven't we discussed this enough? Could you just tell us what you want us to do?

l'd expected puzzlement, but the problem was that even most of the divergent thinkers (most of the class) seemed to reject the subject and its first question. Later, in their first play letters (about thank you for holding) they both discussed the subject avidly, and recalled how they'd rejected it at first.

Scarlet: At the beginning of the honest I thought this show was well...absolute Rubbish.

Martine didn't get her instructions, but the class got the opposite, a whole week of improvisation. We used drama conventions to imagine semi-automated worksites, and perform workplace rituals. For this work, the kids stuck to friendship groups. The Call Centre of Singularity.com- a retailer selling online games, my suggestion- got repeated airings. Operators (named after celebrities, names changed daily) were becoming semi-automated through their scripted responses to customers; we used a carousel technique to show off each group's work. The word play loosened things up generally.

In an improvisation on taking calls, early on, I was complaining about my old mobile, half in role. The kids knew its issues, and decided I needed a new one. There are all kinds of deals Mr Biz! I knew I wasn't supposed to in class, but I mischievously asked if I could actually ring 2 Degrees- a phone company- and the kids were all for it. They were dead quiet when I made my 'prank call'. And I got the option to speak to a real, automated operator. This was real mischief. Of course they'd heard such voices before, but my call's mix of pretend and real sharpened their awareness of these voices. Mr Biz's weird idea about automation replacing humans wasn't his idea after all.

After a fortnight, I put the question again. The task was to write a one line pitch for a Singularity play, but some wrote a paragraph. This time it wasn't just my question, and the kids overcame their opposition to me, and we moved as a class in the way Saitou suggests, to share future horizons, and also evoke possible fictions. The pitches ranged from automated home comfort to Robot Armageddon; here were the first signs of the many voices of the authors. From then on, whatever the children said or wrote, and wherever, there was further talk about it, just because their ideas were different, incongruous.

Stirling: ...But what happens when there is a power cut. Think about 2001 employees, some on the phone, some discreetly playing computer games, some microwaving soup and some on the loo...

One image held the kids attention from early on. It came from a play book, was discussed, became part of devising, then of informal performances, and later, of the online fiction. Last, it became the last scene of the first play 'thank you for holding'. In this scene the stage was empty, lit by a single light, while over it the automated voices of the once human operators played, and the voice of the Operator in Chief.

Clara (first, in playbook): The one blinking light in the room smiles lazily at the deformities mankind has created as a companionable substitute... 
Clara (later, in the interactive blog fiction): An endless empty room with a single blinking light, and no-one knows there is a secret passageway.

This image was linguistic and aesthetic. The kids came back to it over and over, they accepted its power. I can explain its draw now, in the light of Gadamer's reformulation of aesthetic- aesthetic not as subjective, as a matter of personal taste, but as a meaning that has a centrifugal pull, that grips us outside of our intentions.

Nicholas Davey: "Aesthetic experience is the experience of something acting on us contrary to our willing and doing. In other words, aesthetic experience is annunciative, an event to which we are subject" (373).

The annunciative meaning of such images thickened over time, as when Clara later added the secret loophole. As an act of individual imagination became more and more interactive, and part of our fictional world, I didn't know where else the kids might be taking it. They still had their private and solitary spaces.

In one of the very last online posts, post fiction, post class, post primary school, Clara returns to the last blog knowing that this time, no-one is there. She changed its name- Sooner or Later- the second play's name that is, to function as an adverbial phrase; that is the class's story has moved from its imaginative domain to become a possibility in the real world.

Clara: Whether or not our Earth is destined to have the fate of the parallel universe in which the society has collapsed and the singularity has enforced its rules, is still to be decided. Maybe we will get the chance again to play our part, this time in reality. Sooner or Later we will see...

After the first burst of writing in the play making- the singularity pitches- I sparked a lively discussion by asking the children about the role of technology in their lives. What would be the hardest thing for them to give up, for a week or so? After the discussion, I announced that our experiment for the week was actually to do so. At first, the kids saw me as the author of their misfortunes, but then, I did give them a choice.

Moana: Mr Biz smiled while we were tortured with the thought of not being able to use these things for a week or more, then happily announced that that's exactly what we were going to do! $\mathrm{Oh} \mathrm{Mr}$ Bisley, how we disliked him at the time.

It was an old school game- that banding up against the teacher. But no-one turned down the task, and the dislike passed. It was winter, and I gave up heating. I set up a blog (more a forum, but blog was the name the kids liked) called The Sacrifice. They found their posts drew an audience, both online and in their homes. They performed, responded and reflected, as the occasion demanded. They asked questions of each other, responded, gave advice etc.

Sally: Stirling, just a tip, you could crush the sugar cube then it would be some random shape, not a cube. Is it just me, or is everyone sleeping on the floor noticing that they get extremely strange dreams? And their blind is broken so those little flashing UFO lights flash on their face at 4am? Hmm... Nice picture Stella, it is very informative. Mr. Biz, about the heating thing, can you bring Peg to class so we can all check she isn't hypothermic? Andrew, try not to burn the book. I am sure your parents would be very annoyed at Mr. Biz for that, as all of this was his idea. 
The kids were more solicitous for my dog Peg than for me. As the discussion spread out into the online space, and back to the discussion space, I saw that most of the class had decided to share their experiences. And they were adamant- they couldn't break their fasts, even if they were told to. They'd made a vow hadn't they! They were almost teenagers, and this was a power they liked but weren't used to. You could blame the teacher if there was trouble.

This was the first carnival of the plays, and it stretched to school. No heater in the classroom, no watching the screen, no sitting down, no MP3 player, no cubes etcetera- no wonder some other teachers weren't amused. We played courtroom dramas in which I was the judge. Michael, who'd given up utensils had to go to a dinner party. His dad insisted he'd have to eat with a knife and fork, and the kids were gleeful. They made me negotiate on his behalf. Our compromise- a fork.

Getting through the ordeal, that was a matter of pride. These fasts were for real, and became theatrical, because of the audience. And out of the kids' experiences, as diverse as their fasts and their families were, shared problems emerged that gave the original question some grip. If technology was so built in to life and so important, did you really have any choice about using it? Some shared the discovery that when it was removed, your thought changed to, so that was a new horizon. Maybe there was an alternative horizon to the Singularity one. I was a wet blanket however. No heater and I was just cold (my dog was fine).

Andrew, Days 5 and 6: "The sacrifice is nearly over, and so is my sickness $i$ hope. But $i$ woke this morning to the sound of a match. it turned out my thoughts had had an effect on my family too. It was Dad he was lighting a candle in his room too. Wow he has come a long way. so $i$ got up at 8 30(i'm purposely sleeping in until the sun is well up) went downstairs to watch the game of cricket $\mathrm{i}$ recorded on my sky. The clouds were overhead so, just for fun and as a ceremony for the last day of the sacrifice $i$ got all the candles in the house and lit them in my room and boy did the room glow. It was like i 17 th century disco. I can make the sacrifice fun...Even on Day 6.

These performances were reality changing. The performers had to defend their special awareness against the normality around about. Ranciere's theorises how small changes in everyday perception can transform the way we see the world, and might it be that these small theatrical events, with their perceptual shifts, were initiated a series of similar events that culminated in the class remaking itself? The kids set up theatrical events that disoriented them, what Ranciere calls "events of appearance".

David Panagia: "By "event of appearance" I refer to the power of monstrance or perspicuity that appearances have, and their capacity to disrupt conventional forms of looking, of hearing, of perceiving." (103)

These events drew an online audience too, and raised the profile of our subject. I kept a low profile in these events, as following on from The Sacrifice, the kids worked out their rules and limits of their role play, as in their younger play.

From the Sacrifice on, a theatrical aesthetic took on, and the class started collecting, swapping, and mixing its languages. I'd also add that the subject took hold not as it does in a traditional discipline, not as authoritative, but as interactive, an interactive fiction that once picked up, couldn't be put down, because it was incomplete and puzzling, and asked for a contribution. 
Three weeks had passed. As well as a theatrical aesthetic, we had the start of an intertext. From then on, the look became part of the text, and the text became part of the look. These mixed languages stimulated interaction and imitation; if the shows you saw didn't add up, you could always try your hand.

Clara's image stirred the children's curiosity. It disoriented them the way the question also did. It stood for the meanings they couldn't quite get. As Julia told us after thank you for holding's performances, it was only when she was acting in the play and got to the last scene that she saw what it meant 'finally'. Her finally met with agreement from others, with a sense of relief. That was the power of their long spectatorship, of meanings that are implicit and evoked, of being in the hold of an image that shifts about, an image that's only realised for some in the heightened material space of performance.

Kids are curious about gaps in meaning, whether in perception or in texts. They like to step and jump over them, and don't want to fill them in. The plays gave this proclivity a work out. This is the curiosity that Tyson Lewis describes as the "capacity to sense things otherwise now, in the moment of perceptual rupture" (111). According to Lewis's interpretation of Ranciere's The Ignorant Schoolmaster, pointing out these gaps, these empty spaces is the role of the teacher artist. These kids did needed some provocation from me to get gap jumping; my co-authorship continued the way it had started.

Three whole terms! A class and I had never had so much time to collaborate on plays. And if the combination of literacies- the threefold take on meaning- formed in a few weeks- it took the whole first term for its relational implications, and the us I am looking for here, to emerge.

Jump to one morning in late July. I'd a dress rehearsal for another play ${ }^{15}$, so I left these kids in the library, with a loose outline for their first play letters. The class worked for an hour and a half, largely unsupervised; I got a good report from a colleague who looked in. And their letters were great, showing the old goal recital had been superseded, more on that later. Later, I heard the inside story from the kids, orally and in their reflections.

Clara: Sitting in the library typing this I realise just how much we have adjusted to our play, as I look around everyone is typing continuously like operators, Tess is even using my phone to make a call to Santa (teacher approved, don't worry) and silence never used to be the object of our rare typing sessions.

Not only writing their reflective narratives, but playing a new scene; making, performing, reflecting all mixed up- perfect! I never thought l'd see a group of kids make such a clean break from the confines of text type writing! I never saw this scene, but I laughed at the thought of it, the thought of the last act of the play as a parody, in the library.

In the light of Maisie's address, I reinterpret the library scene not just as an epilogue to the old play, but as a showing of a new social learning. And what is doubly fascinating are the parodic aspects of this unfinalised event. Take Clara's don't worry. She knew I wouldn't care about Scarlet's parodic phone call to Santa ( a reprise of my call to 2 Degrees), so her don't worry was doubly parodic. She also was letting me in on the joke that the class was actually more engaged in their writing than when I was in control.

\footnotetext{
${ }^{15}$ I wrote a paper- creating the work, creating the self- describing this younger class's contrasting play process through a dialogue with a student. In the 2014 volume of the online journal The New Zealand Journal for the Performing Arts, http://www.drama.org.nz/publications/ new-zealand-journal-of-research-in-performing-arts-and-education-2015/
} 
By the fifth week of the first play term, the antagonist in our fictional world was cranking up a plot; but I had no idea we were soon to go head to head with another antagonist, in an outside fiction. Here there was theatre making, with its blend of imagination and curiosity, there a National Standards regime, prefiguring a seamless, standardised pathway to achievement. Allow me to be your M.C.

Charles Bisley. Roll up, roll up. Push play. A fanfare. (The fanfare that started thank you for holding sounds like the fanfare from Star Wars).

Ladies and Gentlemen! In the red corner, representing a pedagogicised society, an expert on assessment! In the blue corner, representing her creative class, and others- a twelve year old girl!

Ministry of Education Official (to a teachers meeting): [...] and my daughter was excited when I was able to show her where she would be up to with her English... and mathematics... at the end of year $6 \ldots$ and then year 8 .

Sally: Personally, I think we need to have not too many props, leave some to the imagination...And also I think we need cellophane. I dunno why...my brain just thinks light cellophane and cover the screen with it.

How to show the growing power of Hoss, the digital potentate of our play? How to change it? For Sally, working as a dramaturge, the play's evolving Singularity question was also an aesthetic problem. Present Hoss on screen on stage too, but alter his digital appearance, literally. As I read her post for the first time, an image made me shiver. It was the diorama I made when I was six, the way it looked. Yes, the power of cellophane to change the world.

\section{Humour, creative and subversive}

"[T]he author is far from neutral in his relationship to the image of another's language, argues with it, agrees with it (although with conditions), interrogates it, eavesdrops on it, but also ridicules it, parodically exaggerates it, and so forth" (Dialogic Imagination 49)

Mikhail Bakhtin

Along with theatrical style, the class also developed a distinctive verbal humour. Their humour was disinhibiting, enabling them to take themselves and others less seriously, and therefore to interact more freely, as improvisers and authors ${ }^{16}$, to counteract the givens and constraints before them. If the neutral discourse of instruction had confined our interactions, now a shared, anomalous word play set them off.

Hans Richter: "The safety-valve was off. However unsafe and unknown the territory into which we now sailed, leapt, drove, or tumbled, we were all sure where our path lay...And the paths led in all directions" (57)

${ }^{16}$ This freely was not free as in free range learning, or the self=directed unlearning that's trending in some of our schools as our reaction to instrumental regimes. 
I don't think the kids realised how much they were giving me voice, and freeing me up as their teacher. Until they leapt on their hobby horses, I wasn't going far. Lucky for me, they turned out to be Dada natives.

We revelled in wordplay, unhitching words from given meanings and objects. For example, in a class discussion about how to show Hoss and his increasing power, I suggested we could add another s into his name in each scene, so that Hoss became more and more of a hiss. Not to be outdone, Stella jested on-line, reversing my idea.

Stella: Hey mr biz I reckon with the adding more ssss onto hoss that we should start off with heaps of ssss and then get shorter and shorter until it's hos, ho, h.

Our tussle opened up the question of whether the Singularity was empty or full. The word play fuelled the play making, especially online, and the online space aka the blog became a place to hang out, out of school.

Role play, word play- another mix-up! Nonsense, glossolalia, paradoxes, puns, jokes, visual jokes, nonsequiturs, gags, slapstick, satire, irony, black humour, parody. You got to know each other by appreciating the distinctiveness of each other's humour; moreover, joking around in role let you take more risks than as yourself. The voices in role ranged from Stella's skittish nonsense, through Max's heavy black humour, to Clara's allusive irony. The kids were really surprised by this humour in role; they read each other's fictions and fictional selves, and in this way, started an intertext across the five spaces, and made it into a rich language resource which they imitated and parodied.

In The Candidates, the week 6 play blog, the question was how to get a job at its call centre, which was how to get on the right side of an invisible, all-powerful boss. The kids were familiar with the set piece Get in with the Teacher, so had experience to draw on. Stella, for example, plays a character, Usher, who wears out another contestant by a repeated play on two words- repetitive \& pet.

Stella:

\section{woof woof woof}

I'll be your pet

your very very helpful,

\section{repetitive pet.}

I'll sit by your side and bark

not too much

but listen to every word you say

and alkit allllllll in. $_{\text {. }}$

this is a slightly hypnotized worker.

Such interactive play also pushed the development of characters. Here's Maisie's new character Howard, as he first presents himself to the boss. 
Maisie: ...My lifes ambition is to walk through the middle of state highway one. With a huula hoop that has UTOPIA written on it...My lifes ambition before that was to get a purple and green affro, with a W written on it. But after that was completed I realised that Howard started with a $\mathrm{H}$ so now I have a W on my head.

How we laughed over this anti-hipster! In this scene, the anomalous becomes the subversive. Look at this 'clueless' jester, whose bodily inscriptions take the mickey out of words, the words Maisie had pinned to her too (she hadn't had an easy ride at school). The kids were discovering the creativity of the sign, of the world as full of languages; as Holquist writes, for Bakhtin "anything that means is a sign, and since there is nothing that may not function as a sign, everything has the potential to mean" (49). The likes of Maisie didn't take the world as read anymore, and others tagged along.

You had to take it allIIIIII in. The laying hold of things in the improvising space was mirrored by the laying hold of words as things in the online space. This was the start of a new creative discourse- words became animated in the fiction, like props, like repetitive pets.

In discussing the contrast between Piaget and Benjamin's attitude to the development of logical, conceptual thinking, Susan Buck-Morss notes that whereas Piaget only registered the passing of prelogical thinking as inevitable, its disappearance gave Benjamin pause because he saw it as a distinctive form of cognition, creative imagination.

Susan Buck-Morss: "Children's cognition had revolutionary power because it was tactile, and hence tied to action, because rather than accepting the given meaning of things children got to know objects by laying hold of them and using them in a way that transformed their meaning" (85).

This class's improvising on perception moved between things and words; the effect of this mobility was to unfix meanings, and nothing was spared, not who you were, or your social status. And if you were witty, you got noticed, whoever you were in the pecking order. Early on, on the blog, I noticed how peer group status affected the response you got; some, Maisie included, expressed frustration. Later, as a series role plays, the blog gave each new poster a chance to be heard in an imaginary setting, to gain influence as an author or character. And this influence in the fiction became all about how far out of school you could lay hold of material.

Scarlet/Aaron: Hi my name is Aaron and I work for TV Ziva, Slovakias leading television channel dedicated to documents, astrology and telephone quizes my job is to read out whats up next in the most plain voice I can. Occasionally if im lucky the boss will go out to buy his coffee and while he's gone $i$ make rude remarks instead of doing what is written for me. that is what $\mathrm{i}$ come to work for although it only ever happened once i still have hope that maybe one day he will do something not normal but for the moment his day is going to work, send lucas out for his coffee, drink it, take the little tab bit off the cup and put it on his hat, yell at me then go home and he does this every single day. religiously. I once heard about a man who added ss's to his name to make him more powerfull oh how i want to meet him! maybe it will work for me?or are a's less powerful... and on that notestay tune for frantisek maria and later we have stars, from the beginning

The medium may be the message, but Scarlet's not sold on it. Like Maisie, her language has an improvised, out-loud quality. It's authoring and acting simultaneously, a process where sentence boundaries are over-run, and inside and outside overlap. Scarlet tended to be solitary in class (not in a bad way) and was quiet online, well, until TV Ziva appeared for her. She didn't see herself as a writer, not 
until she saw she could draw on what Bakhtin calls the novelness of life, and started to mimic its heteroglossia, in this case the media's fake events with their babble.

Speak was often laugh and speak. To connect, that was the main thing. Play as a means that was its own end became valuable as the means that disrupted the means to the end, especially those to do with functional literacy and magisterial dialogue. The subject asked for it.

Henry Caldwell Cook: "For the Play Way is not a bunch of contrivances for making scholarly pursuits more valuable, but the active philosophy of making pleasurable pursuits valuable...Play is the one means that is an end in itself, for "that we would do, we should do as we would" (8).

The jingle jangle of the sideshow drew the punters. Or was it a sideshow? The word play assisted the characters into life, enhanced the kids' sense of their own implausibility, their amusement at it. By the third play term, they seemed quite at ease with any incongruity, even their teacher's. And I think this sideshow was vital for Maisie's us, for the playful and humorous way it carried the kids clear of social norms ( the power relation too), without even trying. Hence the episode in the library- a parody of the old linear writing process, and a parody of the first play too, in a new aesthetic/ relational writing process.

Tyson Lewis: "Parody is, in other words, the slightest difference that makes all the difference: an opening for disagreement from within the forms and rituals that are repeated" (48).

Tyson Lewis extends Ranciere's redistribution of the sensible to include theatrical and parodic acts. The kids showed that, in changing how how they perceived, their aesthetic register, they removed themselves from the standard practice of education, to a theatrical alternative. Equally, from Sally with her cellophane on the computer screen, to Scarlet's out of season cellphone call to Santa in the library for example, they took up the parodic and dialogic language Bakhtin says we have as authors, some to the extent that they made fun of our inquiry itself.

Stirling: If people think the onegularity is going to occur then what is the point in contributing anything to society (personally I think the idea of the onlygularity occurring is just a load of bollocks)?

\section{Zones of proximity.}

\footnotetext{
"The semantic structure of an innerly persuasive discourse is not finite, it is open; in each of the new contexts that dialogize it, this discourse is able to reveal ever new ways to mean" (Dialogic Imagination 346).

Michael Bakhtin
}

Over the last play term especially, there was little unease or dissent; several kids didn't like our parodic use of the digital. The blog had become the main space for our play writing after all, but then the play came to criticise the digital world.

Holly: It's hypocritical, using the blog to disrespect technology. 
Critical as hypocritical? Interestingly, there was little dissent over our humorous critiques of school, perhaps because school didn't have the same standing as the digital for these kids? The dissenters thought that digital technology should be the one given off-limits, and their dissent over its use did get some oxygen from the class. Were these kids were the real thing- digital natives, or becoming so, and was biting the hand that fed us their issue?

What John Ralston Saul says about corporate entities being constituted as persons could be relevant. Hoss, the CEO of both plays personified technology in a corporate way. The use of a first name- Hossfor a non-person, a name taken from a character in the television series Bonanza ${ }^{17}$, was of course parodic, and became, in our text the master anomaly in a play of anomalies, and the source of repeated puns and japes.

Respect is big at our school, a core value, and this disrespect for a personified power really bugged some. I was amongst the majority who were interested in the issue, but didn't feel the disrespect. Stirling's riposte, in an end of year blog, was telling. His response also shows how the class's core value was their new creative process, the process that made both their plays, and their us.

Stirling: Hypocritical or not, using technology to create a play against technology really worked for us didn't it?

I'd always intended to disassociate myself from the magisterial voice. I didn't know how to. Even when I got my lucky break using teacher in role, I didn't realise what I was doing, what the innovation would be.

Teacher in role is a drama convention that can shift in your position in relation to the students. It does this, as Bolton explains, by addressing the issue of who owns knowledge (32). I employed this practice in the devising space, joining in role plays, as Dorothy Heathcote demonstrated, with middle status roles that give the teacher some say, but not too much. After a devising session, the usual practice is for the teacher to move back out of role, back to the objective space, where she can reassert her control as knower/evaluator.

After one term of play making, including devising, I didn't usually reassert that objective role, because the play and its theatrical aesthetic was establishing a playful, collective discipline. As in the library event, the threefold theatrical, verbal, and relational patterns washed into the standard space, process, discourse. And those practices didn't need me insofar as the kids were making the exchanges between them intentional and purposeful.

It was In the devising space, in the middle phase of the first play, that a robot- name of Gary- appeared, turned despotic, and morphed into a multi-site artificial intelligence called Hoss who had three avatars and three voices. The kids went off into groups several times to devise him, and enjoyed each other's three-handed voiced shows. The devising spilled over into the writing space, which extended it. Days in the Life of Hoss- they turned out great!

Until this new process, a process including writing, writer's block had stayed massive for four kids in the class. For kids like Max, who was however strong at role play. Back home, around the same time he started role playing online, he wrote his day in the life by parodying a work world he knew from his life world, by copying its speech.

\footnotetext{
${ }^{17}$ Bonanza was a western, a popular NBC television series in the sixties and early seventies.
} 
Max/Hoss: [...]Since I never sleep i am there when everyone gets up. I start off. I ball them up - get to your workstations. time is money. Come on, come on. I can hear gaga on the phone negotiating with a Scotsman - they have a language impasse - the Scotsman can't understand a Texan fool and gaga is asking the guy to say everything 15 times over. It is totally off. I intervene. Sort it out and send gaga to a white room $[\ldots .$.

Hoss sparked discussion too. I hadn't devised as Hoss (too high status) in class, nor joined in the online role plays so far. But when I suggested an episode involving him, I got offered the part. This led to my innovating on teacher in role, and more bending of our five frames, and crossovers. The struggle between the children's characters as protagonists and mine as the highest status character and antagonist raised the online to be the leading edge of our fiction.

It turned out that Hoss, a representation of the Singularity, didn't like questions, and was trying to override the play with a digital rant. Our inquiry shifted to the questionability of being human. And I admit putting on this posthuman mask unleashed a voluble scathing voice l'd never heard myself speak.

Tyson Lewis: "Performance is a kind of parody of names, gestures, and sensations that are not one's own, that were meant for others unlike one's own" (51).

Some of the kids relished being addressed as alien, as slaves even. This new, authoritarian voice stimulated everyone to speak up, across the spaces. The main narrative (now online) was emerging in a series of moves that had tension but no clear narrative curve, more like devising than playwriting. $\mathrm{H}$. Porter Abbot, in asking whether role playing is narrative, quotes Aarseth in whose account of role-playing games users make similar moves to learn more about a predetermined plot. As "intrigues" (37) their moves can push a plot forward into multiple directions.

Norwegian novelist, Karl Ove Knausgaard, in his autobiographical novels My Struggle, makes a distinction between understanding, or knowledge, and meaning, meaning being what children make. His narrative depicts how adults' knowledge is gained at a price, and is antagonistic to meaning, for "Knowledge is distance, knowledge is stasis and the enemy of meaning" (11). These children as meaning makers were not going to take up the knowledge offered by Hoss, the end of meaning. They were becoming more mobile with each post.

The week of The Candidates, we were reading Jaron Lanier's manifesto You Are Not a Gadget ${ }^{18}$. Lanier criticises the Internet's operating system for devaluing the thinking subject, and for making the user computational. These kids, however, became authors in response to Hoss's devaluing/debunking of the human subject. They did this by creating their own characters for the first time in the process. Another first was their use of phrases from earlier writing, theirs and the classes. It's this double-voiced language, to use Bakhtin's term, that gives the speakers' new connection, develops their discourse as shared, in so far as their utterances refer back to and carry forward the phrases of a number of speakers, and their varying perspectives.

Martine/Mr Bisley/Gloria/Voice of Hoss: I've only just got crankin soon the world is gonna be like an airplane- a plane without any passengers knifing majestically through the ether. Silently.

\footnotetext{
${ }^{18}$ The short text of the week was a regular feature of the literacy side of the programme, along with the shared class novels.. Favourites at the time included Black Swan Green, I Capture the Castle, A Member of the Wedding.
} 
The process by which Hoss acquired his voice in the play was dynamic, involving transformations of voice and role. As part of our inquiry into human automation, Martine discussed a bus driver she'd observed. She went on to post as him on a blog, her airplane image expressing his desire to get away from being behind the wheel. Like Clara's empty room, this image became part of the shared, poetic meaning of the play. Later, as Hoss, I appropriated the voice and image, rephrasing them into my end times script. In the actual performances, Gloria played the voice of this Hoss- in a chimerican accent, with a hyper-real intonation that added gloss to Martine's original satire. In this way, between a variety of voice and roles, both fictional and actual, the class developed its own dialogic heteroglossia.

On the stage space, a variety of Hoss avatars had to put up with a raucous agitprop band singing nursery rhymes and making jokes about them. In the online space, the power struggle between Hoss, his retainers, and his employees became dramatic, and required a change in theatricality, to make the text, its look, more of a spectacle. As Hoss, I led the charge in the online multiliteracy, the graphic use of print, layout, colour etcetera- the aesthetic in the linguistic of The subject as an event in another guise. I didn't get the full appeal of the battle with Hoss, until I heard a recording of a post-play interview. Here the kids were discussing the online language.

Stella: Guys can I just say one last thing...like how Mr Bisley used the different type sizes and colours and stuff...it was kind of like reading it as though we were in a play...but we wrote it..so that was a really good way of empathising with his Hosss speeches

So our online acting was a mode of the acousmatic- sound which only has a visual source? As our literacy practices became multiple, as the oral, verbal, aesthetic, theatrical critical, digital, cultural interleaved, the roles of readers, speakers, writers, audience, actors also interchanged. The spaces, the practices, the roles were fully configured for creative learning.

One day we were talking the action from The Candidates when some of the kids slipped into role. Clara, as the Cloakroom Lady, addressed me as Hoss and I responded. Others joined in, there was some banter; the kids all knew the good guy pose was fake, and were being provocative.

Hoss (grimly): Why do people always have so many questions?

(a very long pause)

Nick (calling out): 'STOP!

(The class falls silent)

Mr Bisley (pausing): What's wrong?

Nick (quietly): This has got too real.

The class was visibly shocked, silent. What to do? After a bit I said why don't you guys discuss Hoss. I kept back so they could decide. They decided to fix a boundary between the online fiction and the devising space. I wasn't to play Hoss in the devising space, but the blog with me as Hoss, or was that Hoss as me, could continue and did, almost to the end of the year. Later, it was okay for the kids to play Hoss in the stage space, well his voices, but from off-stage.

In my playing a character who masked the teacher, and the kids playing back, our humour was becoming more subversive, our authorship highly interactive. And the crisis showed how far the class had come from the first term when they'd niggle over much smaller issues. Now they were problem-solving- they could acknowledge their different perspectives in discussion, even as in their fiction discussion was being 
quelled. This crisis was in contrast to the events of The Wave ${ }^{19}$; the society we were enacting in our various fictions did not transfer over into real life as it did back then. The kids' discussion reassured me their developing coherence as a class was not group think, not uncritical conformity. Their online cult playing spurred on the development of its reverse- a polyphonic thinking, Maisie's us.

The Hoss incident provoked a wider variety of responses in the writing space. Some mimicked other's oral views before moving off to their own. In taking different views, this time not in role, I saw they were articulating complex self/other relations- Bakhtin's architectonics- that had first appeared in the blog role plays a fortnight back.

I for myself. Now I think I need to carry my character on. I just need to keep my ideas going and make good contributions to the blog. I also think I need to have a dark side to my character, disagree with Hoss once or twice (Andrew).

Others for me. Sometimes it can be so enjoyable because I feel like I am who I am pretending to blog. A strange sensation. (Stirling)

I for Others. I think that the blog is good because we can share our thoughts through another character, and see other people's thoughts too. (Holly)

The fiction embodied the relational meanings first. Hoss may be entertaining but he demands an unquestioning adherence- the question bone has no meat left on it. The Cloakroom Lady plays the novelist in response. She is knowing in an authorial way, influencing the characters to form their own views, often speaking in riddles or quoting Shakespeare. Morson discusses Bakhtin's distinction between the authoritarian and the authoritative voice as demanding adherence versus attention (321). From week 6 on, the fictions were propelled by this clash of voices.

To oppose Hoss's monologue, his mission, the characters had to learn the intentions of the other characters, and of the other players, to several removes, and thus became intuitive practitioners of the theory of mind. I quote a short session from an exchange that shows this complex relational meaning, between characters, each other, and the intertext. Clara's character, for example, offers a receding series of negations to question an anonymous plotter and the plot he was brewing- coffee poisoning. Her point is that Hoss is no one, and as such takes the real world away from us.

\section{June. Kim: WE NEED TO FIGURE HOSS OUT!}

9 June. Stella: Hossy Hossy don't you

Let your chips go blippety blop

Blippety blop and around and round

Giddy up we're utopia bound

9 June. Kim: Hossy, Hossy, Hoss, he is not the boss, but he thinks he is. If he is not here, he is NOWHERE!!!

9 June. Clara: Nameless, whats the use in putting something in its coffee, when theres no body to drink the coffee. If theres no body to drink the coffee then theres no one to order the coffee, and if

\footnotetext{
${ }^{19}$ In the 1969 school incident called, and fictionalised as, the Wave, a teacher provokes his students to role play a fascist youth party, but losing the distinction between the fictional and the real, the students enact this party in a destructive way in their real lives, and he has to intervene.
} 
theres no one to order the coffee then theres no once to make the coffee and if theres no one to make the coffee then theres no coffee.

If you all plot separately then none of this is going to work, it'll just be a waste of time

I was delighted by Clara's character picking up on Kim's character's melodramatic NOWHERE!! She's quite dismissive in her criticism of the plotters' lone acts so far, and they respond, start plotting together. In a later exchange, these two characters resume their dialogue, an almost Socratic one in which Clara's character reprises Lear's dialogue with Cordelia to make her questioner think more.

14 June. Kim: Why must Hoss destroy us? He could be peaceful, if we altered his wiring a bit. Hoss is nothing but he can destroy us, how is this possible? Answer me, NOW. How does NOTHING destroy usIs he NOTHING?

14 June. Clara: nothing can come of nothing

15 June. Kim: What do you mean; nothing can come of nothing???

15 June. Clara: I mean exactly what i said. nothing can come of nothing. speak again.

With her ironic humour, her riddles, her allusions, her questions, her reflectiveness, the kids became intrigued by Clara's persona, wanted to read her, find out what made her tick, and from her, other characters in this unexplored world. They paid attention to her first in the text; the puzzle was to work out how her character was like her, or not; part of their response was to find out, and this made the writing intersubjective and intertextual. Others experienced this new attentiveness via text, including the eleven, from Stella to Miles, as the growth of a social agency they'd hitherto lacked. In varieties of role, they enjoyed making a spectacle of themselves; their strong voices emerged in the online fiction first, before transferring from their personae to a confidence face to face. For me, however, playing the magisterial voice in the fiction led to a loss of teacher voice in the classroom.

I have never gone for the simple concept of voice; then, even in the discussion space the kids became keen not to just be but to play themselves, and also pick up on others' tones and views for themselves. In their reading, rewriting, and enacting other's' language, I think these authors came to take up their text as other too, as part of the complex architectonics that generated Maisie's us. In the last term, that included the ambiguous other relation you had with your character.

Michael [ commenting on his character Prom]: We were kind of a bit of both- dissimilar and similar at the same time. Just goes to show Sooner or Later means more than just a couple of words typed up.

Indeed. In their play, Sooner or Later the meanings kept their three-fold dynamic. Performing in the theatre or on the blog, led to a reflective discourse about who its authors and actors were, a shared discourse both about each other and about the other in each. The structure of this discourse wasn't finite, but open; even in the performance, the actors found new voices and interactions. It was hard for some afterwards, alone in the writing space and disconnected from the others as an immediate audience, the others for me. 
Michael: All my sentences are disjointed [...] Why is it easier blogging than sitting in front of an emptyish word document? But I'm not allowed to have someone else to think me for me.

After the first play, a majority agreed that the stage performances fell short of the blog's. I suggested that the blog was the play outside the play, and they took that away to think about. A week later. Clara responded to my play outside the play idea. She situated blogging on the border between inside and outside, self and other.

Clara: About the blogging being a play outside a play, the blogging is really part of the play, like the play was inside the blogging, the blogging being a bigger play...Y You're right about it being another way of acting, it's like socially communicating and expressing yourself with the world but still staying inside your own little box of reality, where you can choose anything and virtually experience it. I guess it's a little hard to explain.

For most, the blog became the best space for this communicating, this interchange between self and world. Blogging is speaking from the boundary between self and other, at a distance where you could imagine what you wanted and choose whether to communicate it or not. And this dialogic meaning was not centrifugal, but movement across and back.

Michael Holquist discusses what form of language provides the threshold between self and others (57). Bakhtin's answer, dialogue, accords with the architectonics of our practice, and especially of blogging. Hoss's digital voice, as a dramatised parody of the remote authoritarian voice, could be approached and hidden from. Unlike the authoritarian voice, there were many zones of proximity, ways to approach and appropriate his language.

In the online fiction especially, the kids' characters mimicked, mocked, misled, infiltrated, augmented each other too. I'd never seen this mobility of voice and role before. Their linguistic interactions were plural, diverse, and parodic - in other words, a dialogic heteroglossia. Perhaps the kids saw a bit of Hoss in me, a taint. Maisie's answer did only come after l'd come down from Hoss's lofty spheres, and back into the zone of contact.

Near the end of the first play making, Justine McDonald, the principal, came on an appraisal call. We were having a class meeting, and the dialogue moved across the circle, primed by the stage and online interactions, often missing me out. I was a bit dubious about an observation of me in which the discussion moved from response to response between the kids, with few prompts from me.

Justine McDonald:

Hi Charles,

Thanks for having me in your Year 7 and 8 English class today.

I really enjoyed watching the social dynamics and interactions which were taking place during the discussions between you and the students, and between the students themselves around the play development. It was very obvious that ALL of the students were actively engaged and not only making connections and reflecting on each other's comments and contributions, but also extremely confident in the way they addressed each other, and the issues they were discussing. This is very pleasing to see. I felt that given the context you had set up with the class the students were given the platform to speak freely, and without worrying about peer pressure and expectations which seem to hinder this age group at times. You have provided the opportunity for them to be removed from 
their own identity and take on the role of someone else, which has obviously provided access to a whole new level of thought and discussion for the class as individuals, and as a group. [...]

Idyllic was my word for this speech situation.

In the second play term, the class only met in an online space, and the postings were more about presenting information and collecting pictures, even when there were opportunities for role play and dialogue. A few kids, Maisie included, claimed they preferred online-only playmaking. No offence Mr Biz but you get in the way. You can relate to Hoss best in writing, in the distance, fully symbolic. Perhaps they were responding to his alterity- the other for me as other from me?

I responded by doing Hoss even better when I returned to the class in the last term. And as my online performance lifted, so did Maisie's, despite her view above. Actually, when I was a way, the class lost its way, stopped collaborating. Two voices were raised in protest.

Sally: Distractions seem to have overpowered us. WHO ARE WE?! This is not EE!!! Where's the deep, deep thought, the posts we have been prided with, the smarts?

Despite these protests, the group didn't get resume their interactive postings until I returned. For most, blog only didn't work. They told me they needed the face to face discussions as well. I talked with a couple of colleagues, and they thought peer pressure had also eroded the group. As we moved back into all five spaces, the class got their their dialogue back. Our new subject took hold too- the idea of children as an endangered species. Its setting was a ruined tower, some time before the Singularity event that was imminent in thank you for holding.

More than a year later, three kids were discussing their old class. They reflected that one reason their current class didn't get as far as their last was because they couldn't communicate as well with each other or with me, and that not having the playmaking blog was the major factor. That blog had been the contact zone, the boundaries where meaning is accessed, exchanged.

Scarlet: Last year's blog was essential to our class, it was the gateway through to our teacher and our thoughts that paper couldn't contain. We needed to go on to make sure we hadn't missed anything. We had a collective feeling of letting ourselves share our thoughts without being looked down on, and imagined a 'no offence' before reading any post others had written about us. Our aim was not to be aimless and we achieved that in any way we could. This class lacked the aimlessly aiming not to be aimless quality.

So l'd managed to dissociate myself from the lofty magisterial. And I did become part of this collective dialogue, in which their was equal access to each other's thoughts

I haven't found an image to represent our mobile meaning making, our creative polyphony; however, I do have an image of what we were not- Erik Whitaker's Virtual Choir 4 singing Fly to Paradise. All those disembodied heads confined to flat screens, displayed in rows and columns of windows arranged in rectilinear blocks, a city of specimens in cases. The affordance of Web 2.0. Homophony as total synchronisation, is that it? And as for that ingenuous-looking cyborg-anime angel, hovering above on the song, she's not much of a zone of contact with whatever is above her. 
With the help of a hieratic Internet, we might no longer need our bodies, our aesthetic spaces, our effort to speak and respond, our creative heteroglossia with its ever new ways to mean. Fly to Paradise shows we can give it all away for a song.

Jaron Lanier: "Communication is now often experienced as a superhuman phenomenon that towers above individuals. A new generation has come of age with a reduced expectation of what a person can be, and of who each person might become."

\title{
a few of you are sounding like transhumans
}

good on you

you jokers need to get ready to dock with

your shiny mother ship HOSSs

\author{
nightnight earth
}

and nature all things bright and beautiful

you are lost. you are

tiny already 


\title{
8. Children's theatre as a form of activism
}

\begin{abstract}
"Everything is turned upside down, and just as master served slave during the Roman Saturnalia, so during the performance, children stand on stage and teach and educate their attentive educators. New forces and new impulses appear" (in Buck-Morss 86).
\end{abstract}

Walter Benjamin.

From The Sacrifice on, performances and spectatorship became part of the action, and the subject provoked talk all over the place- dinner tables, three way conferences, netball courts. The responses of spectators ranged from curious to hostile, and they kept on coming.

Andrew: It turned out my thoughts had had an effect on my family too.

It was when we came to the problem of how to show Hoss on the stage, that's when the kids saw the outside audience as a problem too. Hence Sally and her cellophane, back in The Subject Takes Hold. A couple of weeks later, Sally foresaw the rocks ahead from her sickbed ( she'd joined the class online).

Sally: Sally. Hey you guys, it's Sally again with a confession to make... being an outsider here makes me see through the glass that is this world. This world with long pauses and extended silence.... Ok, back to business... I am just going to say that some of this might overwhelm a lot of people. I mean, the Singularity is a big concept...

Sally was bang on, unfortunately. From then on I pulled out my old saw- you should never underestimate your audience; except I didn't take my own advice. Later the class realised that the fictional world of the blog couldn't be translated onto the stage, and that this problem went right back to the first speculation, and how difficult that was to get your head round.

The first outside reservations about our subject came from a faction on staff, and they not only tackled me, but talked to parents. And after the performances, some of the audience criticised the unsuitable subject. I guess thank you for holding didn't conform to the standard expectations of children's theatre. Why not $\mathrm{Oz}$, everyone loved that? l'd say that's because they have low expectations of children's theatre, and children as creators. On the up side, there was some agreement that the staging was effective, some that the kids had ownership.

The shock that you'd shocked your parents! It took a lot of getting used to. The kids handled the controversies well; a hard one was false attribution. We know what kids can do, and they don't come up with stuff like this, it went. Some teachers agreed. There was no way Mr Bisley could pass this nonsense off as kids' work.

The fact that the kids couldn't give the adults a satisfactory ( to them) explanation of the story just proved the adult's point. I answered the children's frustration with a speculation. What if your parents aren't as intelligent as you are, in your way? This question led to their agreement that it would have been hard to understand if you hadn't done the work. What I am still intrigued by is how kids can find positive responses from parents troublesome too, for their glibness. Has this to do with low expectations, with parents underestimating what their children have been through as creators, in their encounter with a play. Here's an example from a recent, different context- a free adaptation of King Lear. 
Carly: To hear from parents “you all did so well!" brings up this tiny misanthrope that's been hiding in some unknown, messed up place in my soul. I wish it wasn't rude to say 'YOU DON'T UNDERSTAND' it's the truth though. How could someone understand if they only were there for an hour of the play's life? Sure, most probably can try to see from our perspectives and even imagine and stuff, but they can't understand in the same way we can (because we were there for most of the process of making the play).

Back then there were positive responses the cast liked. Here's one of the curvy class, by email (there were three other class plays).

Esther: It was good to have one thing that night that was really and fully up to the imagination. During the performance, I caught myself having visions of Sauron and the Egyptian Devourer of the dead who would consume you if you had not been good enough to have an afterlife. The only clue that you were given was His voice but even that was unable to stay the same. To me, it would appear the Hoss was the new generation of a space time continuum that would take your soul from you and in turn give you eternal power.

Another way to discuss the play warts and all was to examine it forum theatre style. ${ }^{20}$ The kids played their characters, themselves, and a selection of the adults who were invited to comment on the play. I half role-played a bemused but interested parent ( the role of an intermediary). The perspectives ranged from Julia's performing as understanding the play, 'finally', to Maisie's the performance was our imaginative world 'set in mud'. In this, the most serious controversy of the year so far, the kids disagreed amongst, and with themselves, especially later in the writing space. However else, the night performances were seen as an advance on the improv and showings, for the rhythm of their interactions.

Maisie: My moment of power was when we were typing at the start (that looked and sounded awesome!) and I said "one SINGULARITY 3d on its way" and Sacha's line went I'm sorry sir, we do not deal with private citizens, have a nice day..." it rolled together perfectly, and our lines merge together at exactly the right moment. It was like a little tune-almost!

To give the chance for reflection at some distance, I set up a new blog The Critic. There I wrote up my inclass role play as a letter from a puzzled but well-disposed audience member. The kids chose to respond in role.

Miles: You seem to have a lot of questions. I don't like questions. They mean I have to do some talking to answer them. And then my jaw gets sore. I don't like that. Just remember, while you're gathering answers to those questions, don't lose your footing, otherwise you will have to start from scratch, and heed the warnings; unlike the polar bear in my picture. Well, you'll have to be careful, because there are those people that won't give up the information you want without a fight, or there are just those people that won't want you to know anything.

P.S. The sign says "Watch for Ice". Who knew that polar bears can't read?

Miles adopts a high status role- he changes the game to one adults are more used to, who has access to what. He wittily mimics Hoss, and uses the fate of the polar bear in his blog picture as a warning to the

${ }^{20}$ Forum theatre is a practice created by Augusto Boal where audience members are invited to respond to and comment on events in a play, especially the problems of the oppressed, with the help of an intermediary called the Joker. 
reader/critic of the consequences of getting it wrong. This is not the docile, conflict--shy boy of the old days. In a cheeky reversal, he puts the adult reader on the wrong end of the educational practice. He tells us "The sign in the picture says 'Watch for ice!" " He has to tell us, because the small print on the image is too small for any critic- whether polar bear or human-to read.

By not conforming to children's theatre as harmless entertainment, both plays became, as in Benjamin's formulation, a Saturnalia. Or as in Bakhtin's, a co-creation of images as aesthetic activism. The audience had been challenged to think about far more than a rather kooky play. And I wondered who amongst our adult antagonists would have been able to outwit Miles and his band. Miles who'd been only able to write to order, but could now take the class's emerging discourse about learning to outsiders, to engage expert and populist discourses, the disparate fictions.

Paul Fairfield: "Becoming literate in this sense means developing the capacities of intellectual agency, and where agency signifies not only that one knows how the conversation has unfolded to this point, but how to carry it further" (560).

These kids were indeed literate, and were able to engage this dissent because their conversations were internally persuasive. l'd add that the agency they felt as performers made them strong too. Many felt the flow. You fully realise your character in a process that takes place in a charged, aesthetic space outside yourself, and yourself in relation to that character and that space ${ }^{21}$.

The full performances extended the architectonics of the making phase; they were where the kids encountered multiple others: the character you fully embody; the material semiotics of the stage; the presence of the audience. Erika Fischer Lichte discusses the tradition of theatre and acting as being "transformative" for the actor in the performance (170), and proposes a new "transformational aesthetics" in which transformation extends beyond the performance. Given that the kids made transitions between all five spaces for meaning making, given their mobility and cognitive variability as inquirers, given their new way of learning with its shared internal discourse, the lines between process and product, and devising and performance, dissolved.

Gavin Bolton: "In the former one submits oneself to the experience: in the latter one projects what one has already determined" (Selected Writings 14).

It was like a little tune- almost as Maisie said. A pattern one creates and submits to, not unlike experiencing your character (and others) on stage, as more the other for me, outside of you, than the I for the other. This process of relating to a character is heightened by the finalised performance of that character.

Clara: When I was performing the Cloakroom Lady Sililoquy. It was like performing the life story of maximum power; it gives a sense that this character has had a long and complicated life and knows so much more than you so it gives a slightly intimidating vibe, like the character has your life and fate in their hands and everything depends on their decision.

Her on-stage vibe stayed with Clara (and others), so much so Clara tried to write her old character into Sooner or Later, and was averse to new ones. I thought her attachment seemed like loyalty for the knowing she'd got from her, that experiencing people you hardly know, thinking with their brain, speaking with their mouths.

\footnotetext{
${ }^{21}$ I refer back to Foucault's argument that you know yourself not in relation to yourself, but "in relation to a creative activity" (351).
} 
Justine got to hearing a lot about the plays in her office, but she spared me the details. She wouldn't tell me who the agitators were, but I could tell from the kids anyway. In the end, one kid couldn't stand it anymore, She burst out to us what she thought of her parents' moves. I suggested to Justine that we stop Sooner or Later, but she said not to. It's only a few parents, and the kids'd be so disappointed. So yes. We carried on. We had the odd quiet chat. And some went off and reflected on the conflict in one of the quiet, writing spaces.

Scarlet: I know my teacher will come through in the end whether the logic makes sense or not (even though sometimes I wish there was none). I doubt the "ministry of education", or "the national standards" would stand for that, so that's why I say, Mr Bisley my little or rather big friend, I would fight until the PTA says YES to no logic learning!!

The PTA is the parent teacher association. No logic learning, National Standards, the Ministry of Education- that's not my language with the kids. I became curious about what else the kids overheard; it was clear from reflections like Scarlet's that the debate among parents had widened to being about the curriculum in general, even teaching as inquiry. The mood in the press was that teachers needed to do as they were told.

A colleague told me the kids really empathised with me; I replied I had noticed we were becoming tighter as a group. I wonder if the conflict helped Maisie decide that I did belong to her us. I regret my comment about the intelligence of our antagonists now. Often parents get their compass on learning from their school experiences; some were all for the new, retrograde National Standards policy and were influenced by the populist 'debate' in the press, and the sabre rattling over teacher accountability. I would now follow Paul Fairfield and argue that the hostile faction was not as literate as the children. Some parents just couldn't join in the conversation.

Wellington's a small world. One day in the third play term, over a cup of tea, an acquaintance associated with the community told me where I belonged. She half-voiced the community's questions about me, and her conclusion contrasted with Maisie's, no surprise there.

Susie: I had a coffee at Mode [the café in Kelburn] the other day... you really are seen as a maverick [putting it mildly]... have you thought about what else you could do...other than teaching?

I didn't fall on my sword. I did doubt myself though. I made fun of myself by imagining myself as John Keating, having 'Captain, oh my Captain' recited over me. As for my friends, they laughed when I protested l'd been trying to lie low. They reckon I provoked the conflict. And looking back on this trouble, I see the relevance of Nietzsche's ideas on truth. Our truth involved a moral dimension, one we shared as part of the us, one that started way back with our puzzlement over the subject.

Krzysztof Michalski: "The search for truth, the will to truth, contains within itself moral notions that bind us in one way or another with other people, and as a consequence every truth is also a greater or a lesser force, a threat to or a chance at another" (44).

With Sooner or Later's season, the audience we needed came closer; however, the old debate must have also flared up because there it was, back in the classroom. Now it was Harriet who addressed me directly. She'd joined the class for the performance phase of the second play, and hadn't been involved as an author. Curt one-off responses in discussion were her normal; this time was different- like Maisie, she'd been conducting her own inquiry elsewhere. 
Harriet: Mr Bisley, you knew all along. You knew what was going to happen. You wrote it... the characters and the story. You were Dr Xana, and we were the children. The teachers were the guards. The Board of Trustees and the Ministry were ThinkTec. You knew you were going to get into trouble. Don't try and deny it.

So she attributed authorship of the real life conflict to me. If only, I thought. I denied I knew. The class looked restless. This wasn't the usual pause. Then, for the first and only time, two of the kids swore. Out of total frustration. And then another pause. Fortunately, it was lunchtime.

In Sooner or Later, creative children were relics of a forgotten world. The play itself was an adventure story; it told of an experiment to find how these child relics thought, and ended in the trial of $\mathrm{Dr}$ Xana, the experiment's leader, and her disgrace (she was played by Clara). This fiction was in the adventure genre that Bakhtin describes, with its two way test:

Mikhail Bakhtin: "It places a person in extraordinary positions that expose and provoke him, it connects him and makes him collide with other people under unusual and unexpected conditions for the purpose of testing the idea and the man of the idea, that is for testing the "man in man"' (Problem 105).

In this context, for testing the "human in the child." At the time of Maisie's address, the kids were discussing their play with a visiting teacher. They were taken with his idea that these questions would come up again one day, and they would understand them so much better for having thought about them when they were children. I've often thought about play making as a rehearsal for maturity; the children had come across the idea in Clara's first play letter.

Clara: Now look! Oh how we've advanced. We have completed the ritual, passed the test. From boyhood into man-hood we strive, or in my case, girl-hood into woman-hood. We have the brains of an adult, the minds of the child, the thoughts of an invincible future! But there we were, sitting harmlessly around, gathered in a quiet conversation.

There was no alibi in school, and especially not the alibi of the grades that tell you if are up to the mark. You take on a task, you make the task your own. And only you and your companions could judge whether you've accomplished it.

\section{The transformation of language.}

"Language in use- discourse- is the 'signifying material of both inner and outer life; consciousness is not only 'embodied' in the body, it is embodied in language (discourse). In the dialogic text, specifically, meaning is embodied in the discourse of the character; it is 'embodied', that is, at a remove and without a need for a body" (82).

Alistair Renfrew

And so it turned out the questions the children came to ask themselves, were not only about about themselves, but also about others, and the questions of others, addressed to them. Their starting off selfcuriosity and doubt, their who am I question, led them out into the many locations and perspectives of 
their text and its theatre, both fictional and actual, and to encounters in new social spaces, beyond the practice of education.

Charles Taylor: "This question finds its original sense in the interchange of speakers. I define who I am by defining where I speak from, in the family tree, in social space” (35).

Way back in section 3 I revisited the children's first learning letters; in that writing I saw the first decisive move of this story, the move to become what Alexander Lobok calls the writing person, a person who is ready to be heard by others. By the first performance of thank you for holding, all the kids had dared this move, as authors and actors, and their first play letters continued, reflected on it. The where I speak from, for this class, became an imaginary and aesthetic world, a theatre they could move about in, in and across its spaces. The others they spoke to from there included the crew, the characters, the play, other audiences, the subject, the text, other texts, but first and most of all, each other. The kids not only responded to each other in the play, they responded to each other as if they were in a play. The play also spoke to them, and that was an other relation to, a significant one.

This textual responsiveness, that's in both sets of these play learning letters too. The kids write as bricoleurs, collecting words and phrases from all the previous texts. In these reflective narratives, their performances, their online writing and role playing, their play book writing, their conversations, the script, become intertextual as the blog also was, and with the mix and voices, languages and styles, heteroglossic too. That's a quantum shift from the old reflection as goal recital. As this language was theatrical and relational/dialogic, the kids didn't get swallowed up by intertextuality. They kept their presence; the play kept on signifying to them.

My question here is- is there more to this than collage and reassembly, than the exercise of a secondary associative power that can never gets outside its linguistic frame or its recombinations? Scarlet offers an answer- she reflected that the play and its questions continued on in the writing, and that this continuance showed the difference between writing a story and living one, the difference which makes all the difference. If the play extended further than the straight verbal, became novelistic, translinguistic, the kids' writing would tell us.

Another angle on this linguistic question is to ask what kind of knowing the kids' reflective play letters display. Are their thoughts here an epistemological play, the sort of knowing that Charles Bingham and Gert Biesta propose as an alternative to the fixed meanings of the explanatory order of school? Do they refer to a world of epistemological relativism, where "childhood meanderings are the order of the day" (157). Meanderings I take it, because language is arbitrary, in a good way, as our parodies also showed. Meander was what the curvy class before this one did, self-meandering learners each one. But this class's creative acts were not relative to each individual, not contingent in this way. The class in question had a bond, an ongoing exchange over a question, a deceptive and parodic meander - aimlessly aiming not to be aimless.

Lewis Hyde: "In all such cases, trickster's art involves playing with what I call the second-order articulation: trickster shifts patterns in relation to one another, and by that redefines the patterns themselves" (257).

Trickster is also a gap maker, as we were. Our role and word play was mischievous and subversiveimitative and divergent. You were never quite sure what others meant, and as soon as you wrote, another actor/writer might take your words off you. One thing I do feel reassured about- our creative process with 
its pattern and gap making drew on the autonomous play of children, and didn't curtail its metasocial meanings.

And then there was the overlap of styles and genres in our texts, a parataxis creating gaps, gaps for new meanings (and that was just in the writing, before the other combinations). For example, straight after some improvised out-loud writing on the blog, the Cloakroom Lady writes a long allegory in a prophetic vein that's dissonant stylistically, and brings in new ideas.

Clara as the Cloakroom Lady: Fate is like a forest of trees, the start being a circle of tiny trees. Each seed has a colour, and each colour represents your future. The seed of Hoss is the centre of the circle, an intimidating seed representing the singularity, the future, the end. Around him cluster the spies, the chosen ones, their hearts being a deep grey, they have not reached the standard of black. They represent willingness and gratitude for death. Next come the blank seeds of operators, lifeless automatons that represent the nothingness that the world will become [...].

And it wasn't just mixing up of a wide range of languages, or the spillovers. It was also the variety of settings and auras of the different performances. It was a long way from the machinic ritual of thank you for holding to the magical captivity of the ruin in Sooner or Later.

Charles Baudelaire: "Do not neglect the marvellous element in drama- the magical and the romanesque. The surroundings, the atmosphere in which the whole narrative must be steeped" (30).

With all that contact and with all those gaps, the linear discourse and pattern of school had to crack, break up. The question is where do you go in the gaping hole left by outcomes-based pedagogy? This question takes us back to the DPJ debate about dialogue for education, and dialogue as education.

Eugene Matusov: "Students socialisation in the given, ready-made culture occurs through its transcendence, and critical reflection on it. The curricular endpoints are unknown for the students and the teacher in advance but only looking back and these curricular endpoints are constantly on the move as the participants keep engaging in critical dialogue" (E18).

The shift from the first learning letters, to the second and third (the play learning letters) was from monologue to dialogue; the kids' experience of blogging as socially communicating spread into the other spaces. The first letters had been defined by the use of the first person singular pronoun. I was delighted when I discovered in these new letters that the kids ranged between first, second and third person, and singular and plural (without any instruction from me), how the writing reflected the play, how the carryover theatre in the library was not a diversion, but a turning point in the move towards dialogue as education, a critical and creative dialogue. And I saw the connection with Bruner's concept of the "selfmaking narrative" (78), in which the writer attempt to balance autonomy and commitment. I thought balance between them, like a kid stepping back and forth on the middle of a see-saw.

I keep returning to the class's attentiveness to each other in these letters (and other reflections). This is writing as addressivity- it often takes a half-spoken, transitional form, bearing the marks of the speaker, a speaker identifiable to the audience of participants. The kids share the subject, give room for replies, by expressing doubts and criticisms, by being open to each other about its difficulty.

It's more than a game with two ends though, or one field. The writing is dramatised, speaks in several voices. If the class came to hear itself as a polyphony of voices, you'd expect to hear that polyphony 
reflected in the letters, and internalised, and you do. From my centrifugal frame, I'm seeing the kids move from a simple to a more provisional view of themselves, that is move out from, from their static learning selves too. The kids choose a variety of starting places; they do so according to who they are.

Krzysztof Michalski: Indeed, truth is always my truth and only has meaning only in the context of the life I can call my own. But it would be futile to try and represent that life from outside, like one of the butterfly species displayed in a museum case. (12).

I'm listening to each child's story, not observing specimens in a case.

Miles starts with a question, from own ironical voice to his expressive other, and his letter is an internal dialogue as to what the expressive other really thinks about the subject, and in fact, why it's even worth considering at all.

Miles: Well, what can you say about the productions? Anything?

Max, first author of Hoss, as Hoss the robot, Max whose favourite space is the acting space starts by quoting his character, Hoss's Head of Security, and then jumps out into commentary.

Max: "You would have noticed a lot of vermin getting in lately

Lt Karmov of the CCCP

That was the longest line I spoke in the marvellous play...

Tim, influenced by home disapproval of the alternative programme as it turns out, takes a parental view from the audience (he gets onto his own role and determined view later).

Tim: I don't know where to start so I'll just say what it felt like the audience were feeling: 'shocked.'

Moana starts from the start of The Sacrifice, and addresses the teacher from the class, already quoted (as it turns out, the class has moved on). Scarlet address is close and personal, to her critic, who is me (next, she abandons this start as unpromising).

Scarlet: Ok here goes...now try not to be too harsh eh?

Sally re-quotes and parodies The Cloakroom Lady's warning to amuse herself. The first syllable of recorded time is Hoss's, and the last syllable of recorded time is Hoss's is copied and corrupted into:

Sally: The last syllable of recorded time is Hoss'.

And the first of this piece of writing is Hoss'. Hoss'.

Happy now? Anyway, I may as well start with an opening idea that will make me laugh.

Julia shows a mobile sense of self. To write, she moves out of the play; she also moves out of her character. She plays herself, but with her character's words in her mouth. She also switches the medium from theatre to MP3 player. The stage directions change to prompts: rewind, play, pause, fast forward.

Julia: Welcome to Singularity.Com

You are speaking to Julia

How may I help 
You want a letter reflecting on the production?

Can do!

Lets rewind and take it from the start....

Andrew is another who writes dialogically. He collects, plays with the characters and their languages. He recasts Hoss, by deforming his words into the riddle form characteristic of Hoss's enemy, the Cloakroom Lady, his character's ally. But then he goes further, he turns to the subject of the class. He interprets script writing not as the death of the author but as the scripting of the class; making the play didn't just lead to close collaboration, it becomes a metaphor for the making of the class, Maisie's 'us'. Dumb arse! It's a metaphor. Andrew got the metaphor long before I did. I love the linguistic disparity between the two halves of the address.

Andrew: I portrayed a Hosss follower on my life in the play. The Blog was the way of all our characters coming together and talking about the play. Little did we know at the time Mr B was cutting, pasting, copying, printing and writing. Our script, we were the ideas. We were our script (I know it scared me at the time too).

I don't want to be words! I want to be buman

Dumb arse! It's a metaphor

$\mathrm{Ha}$

Maisie was an avid online author, and she started with the blog. l'd already overheard her and Clara earnestly try to explain the gap between the blog and the stage plays to friends from another class, and give up. (Unlike Maisie, Clara liked blogging but her favourite space was the stage).

Madonna: Ride the rainbow to the other side.

I can't stand the adult/media rendition for children of their magical innocence somewhere over the rainbow. The senior choir sings a tacky innocence song-Jesse-say, and all they get is a cartoon world of elephants and pink lemonade. Unlucky Jesse (or is she not a real person?). This genre replaces the real thing with a simulacrum. The last thing we should do is tell them where to go.

Maisie: Learning about the SINGULARITY was like entering a different world that I never knew even existed before. Well it didn't. We created it. Using the blog, on that world we created our own world and characters, ee's very own three dimensional planet.

The ideas behind it were something else. We were an "ideas team" as Mr Bisley put it, and this bright and colourful world was just waiting for EE to come along and create a shape so temporary and complex that fits into the lock to enter into this world that nobody would understand....if they want to "see" your play when you don't want them to, you can just say "sure" and show them the blog, and since they cannot twist themselves into the shape that EE has created that will enter into this 3-dimensional world.

Maisie describes a motion different from Bingham and Biesta's childhood meanderings. The class's mobile meanings were not associative and fanciful; the children's imaginations transported them to a new, radical knowing. If I've been cautious about describing their creativity as transformative, but this 
imaginative and social act is clearly an act of self transformation, and also social transcendence. To elaborate this transformative, l'll have have to extend my three-fold meaning making adjectives to six. This creativity was fictional, critical, kinaesthetic, somatic, aesthetic, theatrical. And if it was another world you had to journey to, it was also inside, internal to the group that assembled there. So my centrifugal, moving outwards metaphor has pulled up short, and I need to have centripetal motion back in there too.

The class's imaginary world has a paradoxical quality, in that it was both waiting there, as a rhythm or pattern for the kids to join, but also as a space for them to create their world in. This paradox a mythical feel, in the sense that the stories told about a myth always fell short, or grew stale, and there was always the chance a newcomer might come along and replenish its meaning, like these kids who'd never been there. To re-consummate it.

The Homeric Hymn to Hermes: "And luck-bringing Hermes, the son of Zeus, passed edgeways through the key-hole of the hall like the autumn breeze, even as mist: straight through the cave he went and came to the rich inner chamber, walking softly, and making no noise as one might upon the floor" (375).

After killing the cattle of Apollo, Hermes returns to his mother's house and lies in his cradle, as innocent as a baby. It's the way he gets in, through the lock, as if he were a breeze, that's telling. The kids improve on his technique, and become momentary keys. More, in becoming the key, they became the lock too. In their mother's house with its rich inner chamber, was that where they met to create their bright and colourful world?

It was Clara who first gave us the image of a synchronised totality, but with one gap, a loophole, her secret passage way, a way out. In contrast, Andrew writes about meaning as aesthetic, as coming in from outside. but not by the usual opening. The play is foreign, has a body of its own, and if you want to take it in, you must re-configure your own. The aesthetic of one body ingesting another, that's living the story as carnival, as a parodic sociability.

Andrew: Our play wasn't orthodox. To really swallow it you must use your foot (not literally, I don't want someone trying to swallow their foot). If you eat it with your hands, your teeth will break and you will stay silly for life, but if you get the guts of it, the meaning and the plot and all the little things come alive. Your brain has too many tentacles. As does Hosss.

All the little things come alive. The play is topsy-turvy, but that doesn't mean it's nonsense. In Andrew's reversal, the guts of it is cerebral, and the transformation the play works on its makers is to make them into a text. I'm finding this transformative reversal hard to get my head around. Was this text- the play and its voices-embodied as 'embodied'- that is at a remove-without a need for a body, to use Alistair Renfrew's phrase. Does this 'embodying' play work as a parody of our actual bodies? And what does this parodic body share with the embodying of other art forms?

Mark Wigley: "In a strange way, the body depends upon the foreign elements that transform it. It is reconstituted and propped up on the 'supporting limbs' that extend it. Indeed it becomes a side effect of its extensions. The prosthesis reconstructs the body, transforming its limits, at once extending and convoluting its boundaries. The body itself becomes artifice" (8-9).

For the young artists in question, the bodily became more tangible because the metaphorical and linguistic gave it a new reach. Making a play on the outside, forming themselves into an internally 
persuasive text, that was a double act. This double act is what makes the children's language more than a reassembling of givens, their knowing more radical than relative. To accomplish this ontological knowing, you had to go further, be drawn right out of your depth.

Sally: What I really want to do, is to be thrown in the deep end. Again. I want to be so out of my depth that the surface is all but a mystery. Something imperfect and malformed lodged in the heart of being.

Which brings me to the limit of this discourse, to the last move in this history of relational meanings that I too became part of, the move which corresponds to Bakhtin's concept of outsideness, and also unfinalisability.

Caryl Emerson: "[...] dialogue, according to Bakhtin, is always "outside" any potential whole, more likely to remain isolated for longer and expected to sustain itself in the absence of transcendental guarantees" (228).

In her last second play letter, Scarlet, for example, re-asks a question her character has, one first written by a co-author, her teacher; this is yet another personal inquiry like Maisie's, but this time from the speculative distance of outsideness, a distance that anticipates a time when the play is in the past.

Mikhail Bakhtin: "To find one's voice and to orient it among other voices, to combine it with some and to oppose it with others, to separate one's voice from another voice from which it has inseparably merged- these are the tasks that heroes solve in the course of the novel" (Problem 239).

Scarlet: Mr Bisley, Scarlet, Kalyx: Could a teaspoon's silhouette be a silver mountain followed by a silver abyss or a silver abyss followed by a silver mountain?

What our teacher really did see in those teaspoons [the teaspoons were images of lost memory, souvenir teaspoons] is a question I don't have an answer for... The teaspoons are the key, the key to the door. What door? The door that will lead us into later. So that's why Mr Bisley liked them so much. Or could I be wrong? Maybe there's more to it. Maybe it's what he saw in the teaspoons. He saw no shadow. In the light he saw a reflection. A reflection. A reflection of himself. That is his +1 . That is the mirror that made him two. I guess he would have felt happy. Just knowing it was there.

Like the play, the us we made was ephemeral. I showed them the door out. The children came to themselves again.

Scarlet's answer follows Maisie's. As the text embodied us, so the mirror made me two. From and in her outsideness, Scarlet can imagine the outsideness of another human being, distant already and again, but also visible in this distance as a character in her fiction now, as he might have once been in his own. 
It is easier for me to write my ideas down instead of saying them out loud. If you got an idea at home you didn't have to remember it for school the next day you could go and put it on the blog. Sitting in a class for ages is less fun than blogging with class members because it is on a computer. It might be more fun but do you learn more from the blog? It was necessary for $\mathrm{Mr}$ Bisley's absence to keep us together as a class. Another thing I found hard was not being able to discuss my ideas with other people. It was difficult to continue the thoughts of Hosss in the blog without Mr Bisley being there to help you understand it. I find I always think clearer when I'm not under any pressure to say something meaningful and explain it in the perfect way. The blog is somewhere where I can really think deeply about a topic. You say all you mean and mean all you say without stuffing up or sounding stupid in front of a visible audience. If you try to talk to someone like your mum for example about this random idea you've had, they don't get it as an EEopian would. On the blog I feel that we think of what we will write, therefore allowing new ideas and thoughts to come into our writing. The blog has got me into a habit of saying worthwhile things because there's no point in doing ones which don't help at all. I think a bit of both is good because we can then discuss our blogging thoughts in class which adds an extra element to everything. I think blogging gives you a sort of confidence that you get on stage when you're acting as a person that is so far from your own self. What was good about writing on the blog is that you really get the chance to write something you wouldn't normally do, like creating a whole new character completely different to yourself. It was cool to think that all the ideas people discussed on the blog contributed to the final play. Hypocritical or not, using technology to create a play against technology really worked for us didn't it. I find it easier to go on the blog when there is actually a need to. Now Mister Bisley has escaped from the Yakusa there is not really a need at all. Face to face can make a statement gain more power. Most people (l'm guessing) find it harder to properly communicate and interact through the internet, it's better for all of us when we have real conversations. I think the blog's changed what I say and what I think about things. Now I tend to think around the box, not outside or inside the box, but around the box. The blog teaches that when you don't think about things you manage to think about them in an improved way?' 22

\footnotetext{
${ }^{22}$ This is a remix of blog \# 13. The speakers are Stella, Max, Sally, Holly, Maisie, Stirling, Clara, Scarlet, Stefan, Andrew, Moana, and Miles. The blue changes with each speaker.
} 


\section{Works Cited}

Abbot, H. Porter. Cambridge Introduction to Narrative. $2^{\text {nd }}$ ed. Cambridge: CUP, 2002.

Bakhtin, Mikhail. Dialogic Imagination. Ed. Michael Holquist. Trans Caryl Emerson and Michael Holquist. Austin: University of Texas Press, 1981.

---. Problems of Dostoevsky's Poetics. Trans. Caryl Emerson. Minneapolis: University of Minnesota Press, 1984.

Baudelaire, Charles. Intimate Journals. Trans. Christopher Isherwood. San Francisco: City Lights, 1983.

Bingham, Charles and Gert Biesta. Jacques Rancière: Education, Truth, Emancipation. London: Continuum, 2010.

Bolton, Gavin. Gavin Bolton: Selected writings on Drama in Education. Eds. D. Davis \& C. Lawrence. London: Longman,1986.

---. New Perspectives in Classroom Drama. Hemel Hempstead: Simon and Schuster, 1992.

Buck-Morss, Susan. “Walter Benjamin, Revolutionary Writer (ii)”, The New Left Review I.129 (1981): 7795.

Bruner, Jerome. Making Stories. Cambridge, Mass.: HUP, 2002.

Cheyne, J.A., and D. Tarulli. "Dialogue, Difference, and Voice in the Zone of Proximal Development." An introduction to Vygotsky. Ed. H. Daniels. London: Routledge, 2005, 125-147.

Cook, Henry Caldwell. The Play Way: An Essay in Educational Method. London: William Heinemann, 1917.

Cope, Bill and Mary Kalantzis. "Multiliteracies: New Literacies, New Learning." Pedagogies: an International Journal 4 (2008): 164-198.

Csziksentmihalyi, Mihalyi. Flow: The Psychology of Happiness. London: Rider, 1992.

Davey, Nicholas. "Hermeneutic Aesthetics and the Problem of the Imagination." Gadamer's Hermeneutics and the Art of Conversation. Ed. Andrzej Wiercinski, Berlin: Lit Verlag, 2011. 339-352

Emerson, Caryl. The First Hundred Years of Mikhail Bakhtin. Princeton: Princeton University Press, 1997.

Fairfield, Paul. "Dialogical Education?" Gadamer's Hermeneutics and the Art of Conversation. Ed. Andrzej Wiercinski, Berlin: Lit Verlag, 2011. 553-564.

Fischer-Lichte, Erika. Routledge Introduction to Theatre and Performance Studies. Eds. Minou Arjomand and Ramona Mosse. Trans. Minou Arjomand. London: Routledge, 2014.

Foucault, Michel. Essential Works of Foucault 1954-1984, Volume 1: Ethics. Ed. Paul Rainbow. London: Penguin, 2000.

Gadamer, Hans Georg. The Relevance of The Beautiful and Other Essays. Ed. Robert Bernasconi. Cambridge: Cambridge University Press, 1987.

Gallagher, Kathleen. "The Aesthetics of Representation: Dramatic Texts and Dramatic Engagement." The Journal of Aesthetic Education 39.4 (2005): 82-94.

Hesiod. Homeric Hymns. Trans. Hugh G. Evelyn-White. London: Heineman, 1920.

Holquist, Michael. Dialogism: Bakhtin and his World. London: Routledge, 1990. 
Hyde, Lewis. Trickster Makes This World. New York: North Point Press, 1998.

Knausgaard, Karl Ove. My Struggle: Book One. Trans. Don Bartlett. New York: Farrar, Straus, and Giroux, 2013.

Kotsko, Adam. Awkwardness. Winchester: Zero Books, 2010.

Lanier, Jaron. You Are Not a Gadget: A Manifesto. Camberwell: Penguin, 2010.

Lewis, Tyson E. The Aesthetics of Education; Theatre, Curiosity, and Politics in the work of Jacques Ranciere and Paolo Freire. London: Bloomsbury Academic, 2014.

Lobok, Alexander. "The Writing Person." Journal of Russian and East European Psychology 50.6 (2012): 34-70.

Matusov, Eugene, and Kiyotaka Miyazaki, "Dialogue on 'Dialogic Education”, Dialogic Pedagogy: An International Online Journal 2 (2014).

Matusov, Eugene, and Rupert Wegerif, "Dialogue on 'Dialogic Education'; Has Rupert gone over to 'the Dark Side'?" Dialogic Pedagogy: An International Online Journal 2 (2014).

Michalski, Krzysztof. The Flame of Eternity: An Interpretation of Nietzsche's Thought. Princeton: PUP, 2007.

Miyazaki, Kiyotaka. "Teacher as the Author of Polyphonic Novel: Bakhtinian analysis of a Japanese view of dialogic education," Proceedings from the Second International Interdisciplinary Conference on Perspectives and Limits of Dialogism in Mikhail Bakhtin. Eds. Karin Junefelt and Pia Nordin. Stockholm University, 2009. 200-219.

Morgan, Norah and Juliana Saxton. Teaching Drama: A Mind of Many Wonders. London: Hutchinson, 1987.

Morson, Gary Saul. "The Process of Ideological Becoming." Bakhtinian Perspectives on Language, Literacy, and Learning. Eds. Arnetha F. Ball and Sarah Warshauer Freedman. Cambridge: CUP, 2004. 315-332.

Myhill, Debra and Terry Locke. "Composition in the English/Literacy Classroom." English Teaching: Practice and Critique 6.1 (2007): 1-10.

Neelands, Jonathon and Tony Goode. Structuring Drama Work: A Handbook of Available Forms in Theatre and Drama. Cambridge: CUP, 2000.

Nicholson, Helen. Theatre, Education, and Performance. Basingstoke: Palgrave Macmillan, 2011.

O'Toole, John, Madonna Stinson, and Tina Moore. Drama and Curriculum: A Giant at the Door. New York: Springer, 2009.

Panagia, Davide. "'Partage du sensible': the Distribution of the Sensible." Jacques Rancière: Key Concepts. Ed. Jean-Phillipe Deranty. London: Routledge, 2010.

Ranciere, Jacques, The Ignorant Schoolmaster: Five Lessons in Intellectual Emancipation. Trans. Kristin Ross. Stanford: SUP, 1991.

Renfrew, Alistair. Mikhail Bakhtin. London: Routledge, 2015.

Richter, Hans. DADA Art and Anti-art. New York: Harry N. Abrams, 1964.

Solway, David. The Turtle Hypodermic of Sickenpods: Liberal Studies in the Corporate Age. Montreal: McGill-Queen's UP, 2000. 
Taylor, Charles. Sources of the Self. The Making of Modern Identity. Cambridge, Mass.: HUP, 1989.

Verriour, Patrick. "Drama, Distance and the Language Process." Language Arts 62.4 (1985): 385-390.

Wrigley, Mark. "Prosthetic Theory: The Disciplining of Architecture." Assemblage 15

\section{(cc) EY}

New articles in this journal are licensed under a Creative Commons Attribution 4.0 United States License.
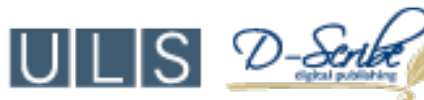

This journal is published by the University Library System, University of Pittsburgh as part of its D-Scribe Digital Publishing Program and is cosponsored by the University of Pittsburgh Press. 